University of Rhode Island

DigitalCommons@URI

Open Access Master's Theses

1959

\title{
American Policy in the Sino-Japanese Conflicts 1931-1932
}

Richard Joesph Collins

University of Rhode Island

Follow this and additional works at: https://digitalcommons.uri.edu/theses

\section{Recommended Citation}

Collins, Richard Joesph, "American Policy in the Sino-Japanese Conflicts 1931-1932" (1959). Open Access Master's Theses. Paper 1791.

https://digitalcommons.uri.edu/theses/1791

This Thesis is brought to you for free and open access by DigitalCommons@URI. It has been accepted for inclusion in Open Access Master's Theses by an authorized administrator of DigitalCommons@URI. For more information, please contact digitalcommons-group@uri.edu. 


$$
\begin{gathered}
D 5518.8 \\
C 6 .
\end{gathered}
$$

\section{AMERICAN POLIOX}

II THE

SINO-JAPANESE CONFLIOTS

\section{$1931-1932$}

BY

RICHARD JOSEPE COULINS

A THESIS SUBMITTED IN PARTIAL FULPILLMEMP OF THE REQUTREMEHTS FOR THE DECRER OF

YASTER OF ARTS

III

FIsT0:Y

UNIVERSITY OF RHODE ISLAMD

1959 


\section{ABSTRACT}

This thesis is a study of American polley in the conflict between ChIne and Japan in 1931 and 1932. The d1:pute 1 of tremendous significance snco it wa what has often been oelled the first step loading to world war II. The purpose here is to moke thorough study of the development of Amerioan polioy in the Manchurien affalr and the -vents that occured in Shanghal ariy in 1932 and to draw some conclusion to why American pollcy did not succeod.

The major source of primary research material was five volume of The Foreign Relations of the Unitod Statos, a comprehenafve sccumulation of diplomatic pepers published by the state Department from 1943 to 1949. Also, considerablo attention was given to The Far Eagtern Crisis, tho journal of the man most responsible for the polley of the Onfted Stetes, Secretary of State Henry L. Stimson. The Report of the Assembly of the League of Nations, the body whlch passed final judgment agalnst Japon, the state Dopartment publication, Pelce and Wer, and the Report of the League of Hations Commission of Enquiry were al so utilized.

The major secondary source consulted was The Manchurian Cr1s18, bJ Sara R. Sm1 th, a work publishod in 1948. The chief source of information regarding developments Ithin Japan was War and Diplomecy in the Japanese 
Empire, by Tatsufi Takouchi.

The main finding of this tudy is that American polley was gullty of two major errors. Firat, tho United states tayed out of the dispute publicly for the first two months. The purpose of thls more was to avold fanning the flemes of natlonalism in Japan and give the efvilian element in the government a chance to wrest control awey from the military. The result wes the reverse of wat was intended. The Fallure of the United States to apply strong and open pressure from the beginning and the military successes of this period encouraged the militant nationallets, and the liberal element never had chance to regaln control. The second error was the fallure of the InIted States to cooperate fully with the League of Nations, fallure wich came after the stato Department roalized Its first orror in judgment. The fact that the League was never completely confident of Amerlean aupport ono ouraged that organization to move with extrome caution, and 1 was this type of caution that lod to that body's downfall.

The polley of moral prossure and non-rocognition of the puppet stete of Manchukuo represented, In this writer's opinion, the best possible course of action against Japan, whloh the facts show to be the aggressor. Economlc sanetlons or armod force would probably have resulted in the war overyone wanted to provent. Nevertholess, the action whioh was taken would have had a better chane of success had it been Immedite and the result of close and complete cooperation between the League and the United States. Further, it 


$$
\text { (v) }
$$

would have required a incere offort on the part of all the nations of the world to assist Japan in her economic difficulties.

It 1s acknowledged that such a course would have had no guarante of success, but, it is the fir convinction of the writer that such policy represented the oniy possibility of pesceful and permanent sottlement. 


\section{ACKNOWLEDGMENTS}

It is the wish of the author to express his gratitude to the Ilbrary staffs of the University of Rhode Island, Brown Onlveralty, and particulariy the Providence Public Library for thefr valuable assistance in obtaining the sourco material for this paper. Also, appreciation is extended to Dr. Danlel Thomas, Dr. Frank Pelton, and Prorossor Dav1d Warren of the UnIveral ty of Rhode Island for their advice and suggestions. Finelly, thanks are extended to the typist, Mrs. Ruth Collins, for her tireloss and uncomplaining efforts. 
LIST OF ILLUSTRATIOHS ...............

Chapter

I. THE MURDEN CRISIS . . . . . . . . .

The Growth of Chinege Nationaliam

Japanese Interests in Manchur1a

Frents Creating Tension

The Rallroad Incident

Prospects for a solution

China's Appoal to the League

II. INITIAL AMERICAN POLICY . . . . . . .

The Poliey of Secretary stimson

The League Assumes Jurisalction

The Bombing of Chinchow

The Glibert 18 sion to the Legrue

The Resolution of 0ctober 24, 1931

III. THE STIMSON DOCTRINE. . . . . . .

44

The Attack of Tsitsihar

Stimson' New Attitude

Japanese Intentions toward Chinchow

The Daves M1sifion to the Lelgue

The Resolution of December 10, 1931

The Fall of the Minseito Cabinet

The Renewal of the Attrek on Chinchow

The Note of Januery 7, 1932

The Effect of the Stims on Doctrine

IV. THE SHANGHAI CONELICT . . . . . . .

Pro-Attack Tensi on

Japanese Demands

The Attack

The Japanege Seek Anerican Cood Offlces

The Bomblng of Nanking

The American Proposal

Japan's Rejection of the American Proposal 
(2)

V. THE DEVELOPMENT OF A COMMON POLICY . . . .

The Broakdown of the Shanghal Conference

The Creation of Manchukus

The Reasons for an Open Letter

The Letter to Senator Borah

InItial Lergue Action on Shangha1

Manchukuo Solldified

The Cessati on of Hostilitios in Shanghal

The Resolution of March 11,1932

VI. THE FINAL JUDGHERT . . . . . . . . .

Japan's Answer to the March 11 Resolution Recogniti on of Menchukuo

The Lytton Report

Reaction to the Report

New Japonese M111tary Operations

The League Debate

Final American Statoment

Japan' Withdrawal from the Loague

viI. CORCLUSION ................ 


\section{LIST OF ILLUSTRATIONS}

F1gure

1. Map of the Far East in $1931 \ldots . . .$.

2. Map of Manohuria in 1931..........
Page

8

43 
lished her domination orer that country. Thls attompt by Japan to make China a protectorate was a direct violation of the open Door policy, which had become the besis of American policy in the Far East. In 1899 secretary of State John Hay hod obtained. the adherence of all the great power of the world, including Japan, to this policy which guaranteod equal oconomic opportunity in China and ensured its political and territorial integrity.

Upon hearing of the Twenty-One Demands, the Unfted States roiced objections to Japan. This stand of the United States compelled Jepan to modify her demands. The resulting ultimatum to China did not establish a protectorate over that nation but did solidify the Japanese position in southern Manchuria. The Chinese accepted these modified demand by signing two treaties on May $25,1915$.

The fact that the United states was influential in the partial frustration of Japan's cabitions in China at this timo Increased the bitterness that was growing in Hippon toward her vast nelghbor across the Proiflc. Also, the Imnigration policy of the United States toward Japan was regarded as a grave insult to that country. The Gentlemen's Agreement of 1907, a voluntary limitation by Japan, had not proved too successful, and in 1924 Congress officially restricted Jepanese Immigration. These factors brought about definite strain in the relations of the two countries.

Following world War I, the nations of the world become vitally concerned with attempts to achleve a lasting peace. These efforts brought about $\mathrm{f}$ feeling of optimism that 
Anerlean-Japanese relations were Improring and presented hope that Japen would rospeot the provisions of the Open Door in Ching.

Probably the nost ignifleant step toward the goal of peace was the ereation of the Laague of Hations. The Jnited states, of course, had refected thls organization. Moverthelose, Japan we momber, and most peoplo, Including many Amerleans, looked to the League at the muln hope for peace.

Eren though it falled to join the League, the Onlted States took an active part in the quest for peae in the nineteen twent1es. In 1922 the najor naval powere of the world, Ineluding the Onited states and Japan, agreed upon a tonnage ratio and construotion hollday for capltol hipe at the Wanington Conforence. More Importent to this study, however, was the IIne Power Treaty whlch retulted rrom this mooting. The purpose of this treaty was to specifloally protect China against designing outside powers. The elgning net1ons, whioh gain 1noluded the Onlted states and Japan, agreed to respect China' soverelgnty, ald in maintaining an effective govermont for China, use their Influence to onsure equal econcmic opportuntty, and refraln fron using conditions in China to gain special rights.

Japan, by Igning the Mine Power Treaty, seomed to have given up any ambitione in Chine and rocopted the princ1plo of Chinose indopondenee. This conception galnod strength in 1928 when Jepan becaue ono of the sixty-two algnees of the Kellogg-Briand Pact. Mhis Paot, promoted by 
the United States and France, called for a solemn condemnetion of wor and an agreement that all international disputes would never be settled by other than pacific means.

The multi-nation treaties of the twenties certainly appeared to be a source of encouragement for the cause of world peace, but despite the acknowledgment of international cooperation by the Japenese government, the bitterness toward the United States still existed. Forces of nationalism were growing in Japan wich were to make shambles of the well intentioned efforts of the treaty signers. Furthermore, the frults of the Revolution of 1911 in Chine were beginning to ripen. The Kuomintang, under the leadership of Chiang Kai-shek, gradually was creating sense of unity and nationelism. It become ineritable that these growing forces in both Japen and Chine would eventualiy clash and wi thout question the most likely arene for thet elagh was Manchurla. 
The Far East in 1931

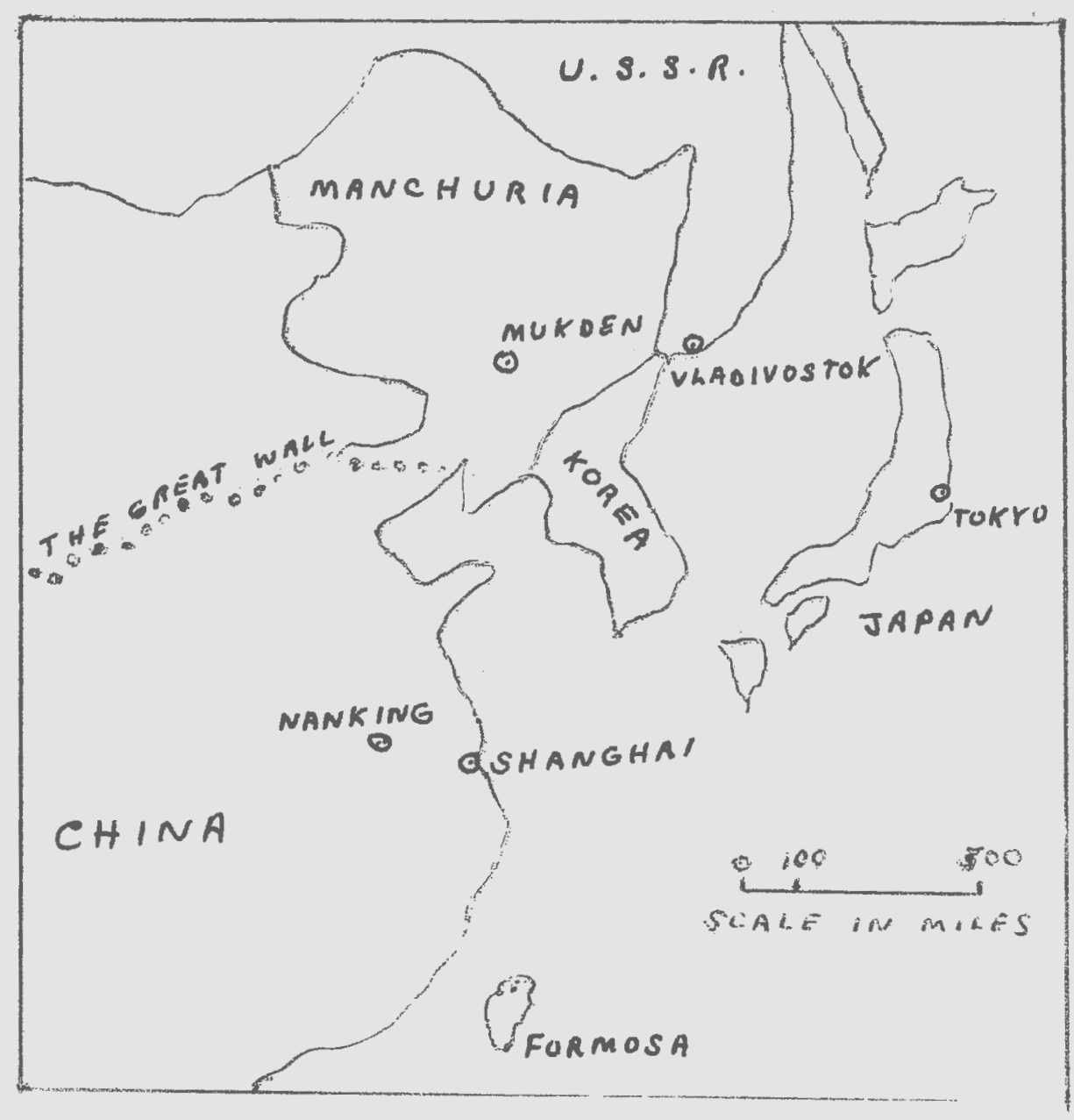

Figure 1 
CHAPTER I

THE HUKDEN CRISIS

By the middle of the 1920' 1 ; the Chinese Mati onal1st. had Inereasd thelr onti-forelgn sentimont conolderably. In the twentios severnl olaches with forelgners erupted in Chinese c1ties, the worst of wioh ooeurred in ranking in 1927. This inoldent reaultod in considerable property danage and the deatha of soveral Japanes, Britlah, and Amorlcan cItisens. Gunbosts of the latter two nations wore lmodiately cent up the Yangte RIver to Manking and, threatened by thi: whow of foree, the Chlnese apologized, peld reparations, and guaranteed further violence would not oecur. Oddy enough, Japanese m1l1tary forees did not participate in this incident. Th1s was hard2y caused bJ a leck of coneorn in Japan but was due to the fact that consorvative were still in control in that oountry and milltant nat lonalian, whioh was to bo the erux of 11 the later afficulties, wa not jet in the open. 1

It would soom that oet baek sueh as this would have hurt the cause of Chlnose nationallan, but that was not the cave. Rathor, the ineldent atrongthoned 1t, for whortly afterward, Chlang Kal-shok asserted thet China would not make

1 Samuel Plagg Bemis, The United States as a Norld Porer (Xow Xork: Heany Folt and Companj. 1950). P. 334 
(10)

any more treaties of concession nor reoggnize those lready mede. 2 such a nationaliotie declaration particularis arfoeted Japan, dnoe hor rights in Mandhuy had boen galned by traties of 1905 and 2915 , whioh were derlattelj treatles of concession, and would therefore no longer be recognized by the Hanking gorernmont.

The fact that China profosed not to rocognise these treatios did not eause Japen to leare Menchuris nor to discontinue the exploitation of hor intereste in that reglon. Hor contlmed precenoe incited the Chinose and aroued their desire to rid themselves of the intruder. The chinese coon found that thol most offective wexon wat the ocmerelal boyeott. The inereaning hardinlp thl bogeott placed upon Jepan, howover, oncouraged allitant attitude there, ono wich advocated postive utops to malntaln Japanose interest: 1n Inehuria.

Douplte Japan' explostation of the region, Ghina had nover consldered Manohums ogything but her own. Baslealiy,

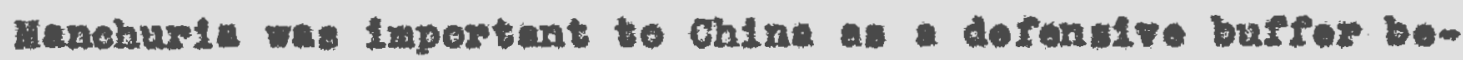
twoon Japan and Rusata and av soureo of food. Umahuria has orton boon called the granary of China seme thirty million Chine farmere had emigrated into the region to oxplot its agricultural potential. At tho same timo, in spite of hoavs commerolal exploltut1 on, for Jupanose razmora had migrated to Menchurie, and in the ojes of most observers, the region was not only legelly Chinese, as the Treaty of Portemouth in 1905 
had osteblined, but Chinese in fact as woll. 3

In Juno of 1928, the Mandaurs an dietator Cheng Tso-11n was asastated in his rallroad car. He had onoe been close to the Japanese but had been gradually drifting away, and his on, Chang Haueh-11ang, whs meeveded him, had bocome even more antI-Japanese. The brokk betweon Manchurla's puler and Japan whs made ecmplote in Decomber of that same Jear won Chang Hereh-11ang dolared allogiance to Menicing and became adminitrative chlef of Menchuria. 4

It would be an understetenent to say that the Japanese had bocome alarmed by this turn of orents. Japen considerod hor Interests in Menchurla to be logitinately galnod and vital to hor welfare. F1rst of all, by 1931 Japan hed olght hundred mill1on yon, or forty pereent of her totel forelgn invertment, t1od up in Manchuria, partieularis in the South Manchurla Rallwey.5 Second, Japan's coonomic woll belng doponded upon her ability to industrilize and her nearest and greatent narkot we China. Also, if Japan woro to ontimue to induatrial1se succesefully, much depended upon her abllity to obtain coel and 1ron from Manohuria. Anothe I recton for Japan's vital interest in Henchure was the faot that posablo volut1on to hor food problem lay in the erops of that region.

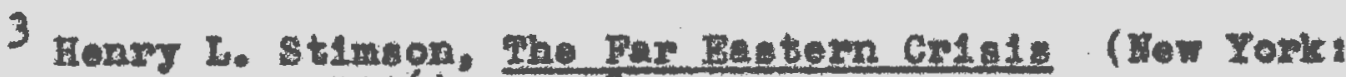
Herper and Brothers, 1936$),$ P. 18

4 I.19... p. 24

5 Elennor Tupper and George E. McRejnolds. Jepan in Ameriem Publle Oplnion (New York: The Mnew111an Company. $1937) .9 .294$ 
(22)

Further, owe Japanese looked upon Henehuria gos postblo outlot for their country's exces population, al though as proviously mentioned, fow farmers had migrated there by 1931 and the total of 230,000 Japanese in Manchuris woro almost all Involved in the running or polleing of the south Manohusia Ra11wey. 6 Finally, although it was not well derined, thore wes fooling in Japan that the thougand of lives lost in proventing Ruseian aequisition of Innehuria in the war of 1904-1905 had glven to the Japanose postition of special interost. 7

Two conflioting ldens to how these interests ghould be mainteinod existed in Japan. Baron Shidohara, who was hoad of the Forelgn Off1ce from 1924 to 1927 and from 1929 unt11 the early stages of the orisis of 1931, had long advoeated a conelliatory polley toward China. Shidehara hoped to wolve Japen' ceonomlc problema by gaining the confidence of China and the reat of the world in rogerd to Japan's motives in Manchuria and, It th this confldence galned, to open rast market: for trede hitherto alosed to the Japanose.

There was, howovor, growing feeling in Japen that only by a more aggreselve polloy oould Japan meintaln her interote in yanchurla and, if it boom nocossary, military force might have to be used. It was this foeling that lod to the intervention in shentung by the less contervative government of Earon Tanake in the later part of 1927. The move was

6 stimson, op. eit. p. 16

7 Tupper and MeRernolds, op. o1t., Pp. 294-95 
(13)

caused in port by the foer of the spreading of Ching's civil strife; it resulted in enother vigorous boycott of Japenese trade by China. Shortly afterwards tempers cooled bit and the Jepanese forces were wi thdrawn, but the seeds of bitterness had been planted and they soon began to grow.

Nineteen Twenty-nine marked the return of consorvative leaderahip to Japan, but by 1931 it was becoming increasingly opporent that Prime Minfoter Yuko Hemsguch and Forelgn Minister Kijuro Shidehare woula have a difloult time maintaining poliey of conclilation toward Chine. The tremendous flood of ant1-Japanese propagande by the government of Chang Hsueh-liang was only serving to increase the influence of the proponente of an agressive Manchurian poliey in Japan. Further, competition fror newly bullt Chinose railroad lines was being folt by the south Manchurlo Rallway and wes causing considerable coneern among the Japanese. 8

The stuetion beceme explosive in the summer of 1931 when ant1-Chinese riots broke out in Japanese-held Korea over the molesting of mlgrant farmers from the latter country in Manchuria. Many Chinese wero massacred in these rlots and the resulting increase of China's boyeott on Japanese trade only intengified the situotion. 9

The most severe cause of tension, however, occurred In June when Japenese army offlcer, traveling in Menchuria,

8

Stimson, op. cit.. p. 25

9

Tupper and McReynolds, op. eit., p. 293 
was arrested and killed by Chinese officials. This was the first Instance of violence agalngt a Japanese military offlcial by the Chinese, and the Japanose press mado considerable copy out of 1t, arousing public opinion and encoursging more aggressive policy. 10

Actually, the Japanese public was not informed of all the facts of this case. The Japanese offlcer, Captein Shintaro Nakemura, had boen traveling in Manchuria posing as an agricultural expert but was in fact on allitery roconnalssance mistion. He was detained by Chinese soldiers whilo on his way to the clty of Tronen. The Chinese considered this detontion atrictly a matter of routino, but upon examinIng Nakamura they claimed to heve found narcotics on his person and also documents whlch proved conclualvely that he was a spy. There is only the Chinese version of the story to go on from this point, but it was their contention that after his discovery Nakemura tried to escape and was shot by sentry. 11 The complete deta1ls of the Nakamura incident may never be known. There seems to be little doubt that the latter's misgion was of an 11legal military neture. Yot whether the Ch1nese had actual proof of th1 and whether Nekamure wes really shot while troing to escape instead of belng executed remains mystery. The Japanese reaction to the caso was no

10 The United States Consul at Mukden to the Minister In Chine, August 20, 1931 - The Forelgn Relations of the United states. The Far East, 1931. III (Washington: Tho Untted States Government PFinting off1ce, 1946), 1

11 Sera R. Sm1 th, The Manohurian Crisis (Now York: The Columbia University Press, 1948), p. 18 
mystery, however, and most people close to the situation felt that this incident was a key factor in the bltterness which poved the way for the crisis in September.

The Nakamura case pointed out vigorously to mang Japanese the need for action in Manchuria. Few wore unaware that the loss of Japanese interests in that area would mean crushing blow to Japan's econony, lready in a precarlous position.

The twenties had been particularly diffleult for Japan, A flnancial panic had occurred in 1920, the terrible earthquake had come three yearg later, and banking crisis and famine had struck in 1927. All of these had contributed to a situation of falling prices, decreased wages, and unemployment. 12 The world depression and the Chinese boyeotts had resulted in fifty percent docline in forelgn trade, upon which Japen so greatly depended. With farms overcrowded, more and more Japanose were migrating to the clties; unless the country could expand industrielly, thoy wald become a burden to soclety. However, wi therkets declining and the sources of raw materials belng shut off, the hope of greater industrialization became less 11kely.

As the Japanese farmer and particularly the Japanese youth looked at the situation, they began to feel that a fundamental reorganization of the economic and soclal order was necessary. More and more these discontented group began to

12 Tatsuf1 Takouchs, War and D1plomecy in the Japanese Fmplre (New York: Doubledey, Doran and Company. 1935), p. 340 
look upon greater exploitation of Manchuria es the answer to their problem and they avalled themselves of milltary leadership with its theories of positive action. 13

It would seem that as long as the Mnselto party controlled the Japanese government and Baron Shidehare romained the head of the Forelgn office, a conelliatory polley rather then on aggressive one would prevall. However, it must be pointed out that the position of the military in Japan at that tim was unusuel. High military official had what was known as alrect access to the emperor. Thus, questions of militery policy were often brought before the emperor without consulting the civilien government, making it possible for the militery to follow course of action of which the government would have no knowledgo. This privilege of direct access gave the military position of great importance and enabled it to carry out course of action in september in spite of Shidehare's conservative polloj.

The milltary had boen much stirred by the signing of the London Naval Treaty in 1930. This treaty re-established the battleship rat1os of the Washington Conference, but these were now considered very unfavorable to Japan, no longer willing to accopt a positi on of Inequality. So great was the opposition of the military to this treaty that Prime Minister Hamaguchl was assassinated by fanatic. The assassination did not result in the fall of the cabinet and Baron Shidehara remained the head of the Forelgn office. Nevertheless, the 
Minselto government, now headed by Reylro Watasulk, 14 found itself in most diffloult position since it was opposed by the military, wich was now convineed that a conciliatory policy would load to Japan's eventual loss of her spocial interests in Uanchuria. 15 Then, with the occurrence of the Korem Plots and the death of Captain Hakamura, the opponents of the government held no doubts that an aggreselve polley in Manchurfe was the only possible solution to their diffioultios, In September of 1931, high Chine se offle1als were well aware of this growling hostility and the power of the military In Japan. In spite of the relatively cooperative attitude of the Japanese government, these Chinese offlclal were convinced thet Japan would attempt to oceupy Manchuria before the close of the year. 16 The United States Minister in China, Helson Johnson, reported this fect to the secretery of state on september 15 with the coment that as long ching adopted an attitude inimical to Japanese interests in Monchurie, ino1dents were bound to occur which could le ad to serlous conflet. 17

It was not long before these foars wero realized. On the night of September 18, 1931, at aproximately 10:00 P.H.,

14 Smith, op. o1t., p. 13

15 Takeuch1, op. o1t., pp. $345-46$

16 Memo of the Minister in China, september 11, 1931 The Forelgn Relations of the United States, The Far Eest, 1931. III, 3

17 The Minister in Chins to the secretary of state, September 15, 1931 - Ibld., p. 7 
(18)

a bomb exploded on the tracks of the Japanese-owned south Manchuria Raflway at Llutioka station Just north of the city of Mukden. 18 This explosion immodiately lod to a clash between a Japane patrol and Chinese forces in the area. Upon hearing the new of the fighting, Lieutenant Colonel Shinamoto, the local Japanese commender, ordered an ettack on the Chinese barrack at Mukden, and by 6:00 A,M. that objective had beon captured. The Japanese did not stop with this success; by evening of the nineteenth the entire city of Mukden was under their control. Within forty-olght hours they had taken all of southern Hanchuria.

The Chinese version of the Incident, of course, was that it had been entirely unprovolsed. Furthermore, they contended that Chineso troops in the area wore under strict orders to offer no reslstance, and followed these orders expl1citig with the exception of one regiment in the Mukden barrack: which had no alternative but to defend 1tself.

The Japanese clalmed self-defense. It was tholr contention that the explosion was caused by the Chinese, and when a patrol led by Lieutenant Kawamoto arrived at the seene to Investigate, It was fired upon by force of Chinese soldiers numbering botwe on three hundred and four hundred men. Upon beling informed of the clash, Lioutenent Colonel Shinamoto ordered on attack upon the chinese barracks where some ten thousend troops were stat loned. 19

18

Takouch1, op. e1t., p. 340

19 Smith, op. cit., pp. 19-20 


\section{(19)}

When Informod of the situation on the night of the elghteenth, General Shigero Honjo, the ahlef comender of the Japanese Kwantung Army in Menchur1a, ordered the occupation of Mukden and the other eltieg of southern Manchuria. The Japanese contention was thet with only 10,400 troops in the entire are as compared to 220,000 Chinese, and with the I1ves and property of Japenese ofvillans in the region in serious jeopurdy, It was necessary to act swiftiy to forestall a serfous dianter. 20

Deepite the Japanose explanation, the awiftnoss and efflelency of 1ts army's movement and bulld up of munitions and supplies make 1 t obvious that this was not apontanpous action. There ves 11ttlo doubt that 1t was thoroughy planned and well expeuted milltary operation. The League of Hat1ons' Comisat on of Faquing rooogntsed this faet but aoknowledged that all armlea make detalled plans for any possible ovontuallty, and the Japanose in this case slmply exoouted fust such plan. The Comisalon did not jastify the Japanese explanstion of self-defonse jet recognized that the Japanose officer: Involved may have thought they were acting in that capacity, and 1t wa not definitely coneluded that the ine1dent at Mukden was deliberato plot. 21

The version has boen refuted in a recent studj of

20 Japanese fmbass to the Department of state, soptember 24. 1931 - The Dorelen Relatione of the Un1ted statea. Japan. 1931-1941. I (Wanington: the Unitod states Government PInting offiee, 1943), II

21

Smith, op. eit. p. 22 
Japanese nationaliom by Richard Storry. Storry's thesis, which he backs with considerable ovidence and which is accopted as accurate by this writer, is that the rallroad oxplosion and the entire incldent was the work of the Japanese, not the Chinese. The operation was plenned in its minutest detall by Colonel Itag1, Lieutenant Colonel Ishihara and Major Hanoya, all members of the headquarters staff of the Iwantung Army and possessors of rersarkable power in that organization. All three of these mon were members of an ultranationsistic society of funior ermy offlcers known ss the Sukuraka1.22 This secret society, devoted to roorganizing the Japanese government long militaristic lines, had falled to execute a goverment coup d'etat in Toikyo earlier in the year and since that time had become more determined than ever to bring about direct action in Manchuria. 23

on September 15 the Japanese Consul General in Mukden reported to the Forelgn office that Captain Kawakam had stated that on important incident might break out on the evenIng of the elghteenth, and he had been entrusted with the captur of the Mukdon alrfield if this became an eventuality. Upon hearing this. Foreign Minlster Shidehara expressed his concern to the Minister of War, General Jiro Minami, who was also questioned on the matter by the emperor. Finaliy, Minami consented to send an onvoy to Mukden with orders to

\footnotetext{
22 RIchard Storry, The Double Patriots - a Study of Japenere Nationaliam (London: Chatto and Windus Compeny, 1957), p. 84

$$
23 \text { Ib1d. p. } 55
$$
}


General Honjo to stop an incident at ell cost. 24

The envoy, General Taketawa, traveled to Mukden by train, arriving on the evening of the elghteenth. Instead of delivering his message promptly, the general doclded to wait until the next day and spont the rest of the evening relexing In a gelsha house. Thus, bofore the mossege whloh was supposed to prevent clach was ever delivered to General Honjo, the fatal incident had occurred. 25

It is known fact that General Minaml was the only nember of the cabinet with derinite militaristic views, and it 1s belleved that he pretended to reconelle the gorernment wh1le cetualy encouraging the military plot. Evidence of this is his lack of urgeney in aending ceneral Taketawa by train instead of by elr, and oven more important, the seloction of Taketawa in the first place. The fact is thet this envoy, who was supposed to go to wukden to prevent an incident which had been plotted by moubers of the Sukuracal, wa none other than the founder of that organization, although the general was not an official member dus to his renk. Thus, the remarkeble incompotence of such a high $x$ anking offlcer, entruted with so inportant tagk, is logically explained. General Taketawa never had sny intention of topping the incident, and the inister of War know that hon he sent him. Storry coneludes by stating that Minami and Taketawe were probably not the instigators of

$$
\begin{aligned}
& 24 \text { Ibid.. p. } 75 \\
& 25 \text { Ib1d.. p. } 86
\end{aligned}
$$


the plot, but gave it the1r whole hearted support. 26

At firgt, reacti on in Japan to the rallroed explosion and subsequent milltary moves was divided. The surprise of the incident brought about ane criticism of the army, especilily by Iruo Oyame, the head of the Jepanese Labor Party. 27 The rightists, however, constantly gained in strength, and the dugs following the incldent passed, the pendulum swang farther and farther tow ard acceptance of the militery's agressive polley. The Solyakal Party, the leadIng rival of the Minse1to, did everyting possible to discredit the condilatory pollcy of the current government. By early December, public opinion had shifted drasticaliy in favor of the milltary. Evorywhere Jepnese citizens had becone convineed that the action in Manchurio in solfdefonse and necessary to Japan's welfare. 28

The Japenose reasoning in this gituation was adequately sumarized by Ambsasador W. Cameron Forbes in a letter to the secretary of stato. Forbes explained that the Japanese were convinced that the intervention was necesary beckuse Manchurie was in chaotic condition, adminitratively and $\mathrm{fl}-$ nenclally, and that the Chinose offlclals there wero unablo to do anything about 1t. Banditry was rempant, end sineo there was no power to enforce ordor in Menchurla except in the Japanese rallroad area, the Japanose had no alternative but to

$$
\begin{aligned}
& 26 \text { Ib1d., p. } 56 \\
& 27 \text { Takeuch1, op. c1t.. p. } 362 \\
& 28 \text { Ib1d., p. } 367
\end{aligned}
$$


protect their interests by ostablighing order themselves. Furthermore, the Japanese were convinced that their oxplo1tation of Manchuria was an economic necessity, and Ince China no longer elalmed to recognize the provislong of the Twenty-One Demands which established these rights, force became necessary to preserve what Japen felt to be rightrully hers. 29

It is intereating to note that Forbes informed stimson at this time that what Japen was doing was right and necosary, but it was boing done in the wong way. In Forbes' mind Japon's position was jugtifled evon though her courge of action was not. This, of course, gade the determination of Ameriean policy in denling with this crisis extremely afficult. The tendeney today is to look upon warichuria as deliberato act of aggression and the feeling is that our poliog should have been determined accordingly. Mis writer does not argue with that contention; in fact bo has pointed out that tho orisis was more of an act of aggrossion than wag generally realized t that time. Nevertholegs, Forbes was correct in polnting out that there were extenuating olrcumstances a far as Japan was concerned. It becomes obvious that these c1rcumstances must be born In mind if one is to analyze properiy the Amerioan handling of the gituation.

one of the big difficultios in this crisis was that the frets were not out in the open. Japan contended her action was

29 Ambassedor Forbes to the Secrotary of state, January 29, 1932, The Forelgn Relations of the United States. The Far East. 1932 , III (Weahington: Tho United statos Government Printing office, 1945), 109 
(24)

-triotly matter of self-defenso and, as bon as the safety of Japanese realdents was asured, she would wi thdraw her troops to thelr original positions. China, on the other hand, malntelned that the attack was otrictiy of Japeneso origin and that it oame with absolutely no prorocation. The Chinese questioned, with muoh justiflcation the stuation unfolded, Japan's intention to 1 thdraw and openly adrocated noutrel 1nvest1gation, course of ection which Japan steadrastly opposed at that time. 30

Japan contended the matter should bo settled by her and Chins alone. Chine recognisod the distrantage of such an axrangement and sought outslde belp. The day following the Intial oleah former ulnister of Forelgn Afralrs, Wellington Koo, visitod the United gtates Minister in China, Nel son Johnson, seeking Amorfican leaderahip in bringing about settloment of the disute. 31 The Jnited states was unwilling to provide such loaderahip and Chine, rocognising that sho rould not get the asurance she sought, declied to being the case before the Lague of Nations. On Soptomber 21 China formelly appealed to the feague, solking restoration of the tatus quo, prevention of a ronewal of the hostilities, and roparations for dameges. 32 Moanth12e, Chiang IaI-ahok, In an adiress made to the loadera

30 stimson, er. e1t., p. 33

31 The United stated Minister in China to the seorotery of Etate, September 19, 2931 - The Forelgn Relations of the United states, The Far East, 1931, III, 12

32 Takeveht, ope elt., p. 354 
(25)

of the Kuomintang, Impressed upon them the necessity of remelning calm wile the oppeal to the Leggue was being acted upon, and being ready to flght if no atisfaction wore rea11 a 33

33 The Minister In Chins to the Secretary of Stato. September 23, 1941 - The Forelen Relations of the Un1ted Statos. The far east, 193I, III, 41 
CHAPTER II

INITIAL AMERICAN POLICY

Opon hearing of the clash at Mukden and the subsequent occupation of southern Manchuria, the United States secretary of state, Henry L. St1mson, Immediately called the Japanese ambassador, Katsuf1 Debuch1, to his office for a conference. When asked by stims on to cancel a planned trip home, Debuch aseerted that he had already done so. Fur ther, the ambessador expressed surprise over the Mukden Ineident and assured Stimson that his govemment would take steps to control 1t. 1

Secrotary Stimson states in his book, The Far Eastern Crisis, that his infial reaction was uncertain as to whether or not the Japanese government had sanctioned the action of the army in Manchuria. ${ }^{2}$ It appears that ho took the assertions of the ambassador at face value and assumed that definite steps would be taken to control the situation. It later became obvious thet such was not the case; the politicel situation in Japan gave one no assurance that simply because a civil officlal of the government promised a course of action, the army would honor that promise. The dual nature of the

\footnotetext{
1 stimson, op.o1t.. p. 25

2 Ibld., p. 31
} 
Japanose government has already been diseussed. There seems to be little doubt that in his initial poliey secretary stimson was not entirely unaware of the special position of the Japanese military but did not attach suffleient import to 1 t.

Soon aftor the Inttial elash, Stimson rocolved communication from Minister Johngon stating that the Nakamura Inoident had raised the tre of the Japanese army in wanchuria, and the k1121ng of Japanese soldiers on the South Manchuria Fallway on September 18 had Ineited it into action. 3 This, of course, was the Japense axpy's verelon, but it aubstantlated the erowing bellof in the army's responalbility for the Ineldent. Flnaliy, on Soptember 21 the stete Department reached the offialal conelugion thet the Mukden incldent was strletly elash mong subordinates and that nelther governments was involved. It was coknowledged that Baron ShIdehara may have feared such a coup by the army, wich 1 t has already boen shown he did, but the Forelgn office was definitely not a party in the action, and the state Department was convinced that in no way could this incident be termed a violation of the Kolloge Paot. 4

Deap1 to the fact that the state Department did not place blame upon the Japanese government, Seeretary Stimson was convinced, almost from the beginning, that the origin of

3 The Kinleter in China to the seeretary of state, September 19, 1931 - Ine Fore1m Relet1one of the United States. The Par East, 1931, III, 13

4 stimson. op.e1t., p. 34 
the slagh was the Japanese army and the Chinose bore no algalfloant responsibility. His agents in the fiold determined this oarly, telegram from Minleter Johnson on Soptember 22 Indloates. Johnson, basing his information on a report from his V1ce-Consul at Hukden, called the Japanese action a definite aet of aggression ${ }^{5}$ and aseerted that the swiftness of the lettor's troop movemonts procluded any possiblilby of the clash being of Chinose or 1 gin. 6

Wile recognizing that 11 armios are expected to bo propared for any contingency the United Stater accopted the contention that the swiftness of the Japanese movenents and the extromely well coordinated and efficlent conduct of the operation were proof that Japan was the aggressor. Waghington coneluded that although the plitary authorities had not actually planned the affair, they had selsed upon minor inaldent to foree general 11quidation of the outstanding 18 auen botween themselves and the chinese in the area. ${ }^{7}$ It is now - lear that the United States was in orror in this assumption but was correct in 1 ta belief that the Forelign office was not reaponsible for the army' action.

\section{5} Peace and War. United States Porelgn Polloy, 19311941 (Washington: The Department of State Publications, 1943), P. 4

6 The v1ee Consul at Wukden to the Uinister in Chine, September 20, 1931 - The Forelen Relations of the United states. The Far Baet, 1931, III, 19-2I

7 The Charge' in Japan to the Secretary of State, September 22, 1931 - The Forelgn Relationg of the United Stater. Japan, 1931-1941. I Trashington: The Unitod States Government Printing offico, 1943), 4 
With this interpretation of the incident, secretary Stimson undertook a polioy which has since recelved much criticism. Assuming the clash was only local incident, Stimson was convinced the Japanese government could handle 1 t. He wa aware of the nationelistic and milltaristic sentiment in Japan and did all in his power to avold difflculties with those lements in order to g1ve Shidehara overy possiblo chance to settle the question. 8

On september 22, Stimson sent note to the Japanese Foreign Office indicating that the Unitod States hold Japan responsible but would give the government every opportunity to work out the problem.9 The note was not made public, nor any absequent dealing, in order to avold antagonlzing nationalists in Japen and moke things difficult $f$ or the gorernment. Stims on's policy of no publiclty was based upon the fear that forelgn intervention would only fen the flemes of militarism. He felt that if the United Statos forcod a sottloment upon Japan it would imply rekindle the old bitterness between those countries and ruin what he called the internetional progress of the pat decade.

Stimson was convinced of the good falth of the Japanese gorernment because the latter had boen following concillatory policy for the past ten years. Shidehera was an avowed adrocate of the principle that Japanese oconomic problems could be wettled by friendlier trade rolations instead

$$
\begin{aligned}
& 8 \text { Smith, op. c1t., p. } 29 \\
& 9 \text { Ibid., p. } 45
\end{aligned}
$$


(30)

of conquest. His govemment had exemplified this spirit of cooperation by bringing about the troop withdrawal in Shantung and participating in the London Conference. Furthermore, the Secretary was aware that many elder atatesmen and business mon in Japan spoke of caution and feared international difficultios, and he hopod that by keoping the United States out of the 1ssue publicly the se lements would combine wi th the government to bring Japanese policy baok into line with western 1deals.10 It is obvious now that stimson overestimated the potential of this faction and greatly underestimated the power of the nationalists. Acting upon the principle of not making public our attitude toward Japan's responsibility and with the assurance of that country's cabinet that it had no territorial ambitions in Chine, ${ }^{11}$ stimson is sued a note to both the chinese and Jopanese requesting that they refrain from further hosti11t10 .12 This apparent stand of the state Department, which Implied dual responsibllity, raised considerable concern gmong the Chinese. Soon after the initial clash, the Chinese had sought American leadership in bringing about sottlement and were worried over thelr fallure to get 1t. Also, the American attitude that governments were not involved and

10 stimson, op. o1t., pp. 34-36

11 The Japanese Embassy to the Department of State, September 24, 1931 - The Forelgn Relations of the United States, Japan, 1931-1941, I, 11

12 stimson, op. cit., p. 46 
(31)

that the Kellogg-Briand Pact had not boen violated came a severe disappointment to China.13

Since the United States would not provide leadership In settling the issue, Chine, a previousiy mentioned, appeeled to the League of Nations for noutral investigation under Article XI wich declares any wer or threat of war a matter of internati onal concern. Japen, of course, favored settlement arranged by her and China alone and would not consent to suah en investigeti on. The United states, following its policy of giving Shidehare every opportunity to bring the matter under control, came out in opposition to China's proposal for an investigation on the grounds that orientals best solve their alfferences without outside interfersnce. Actually, however, Stimson's reason for opposing China's proposal was the fear that an outalde investigation would only inflame Japanese nationalists even more behind the military and make the task of settlement by the government an Impossible one. 14 officialig, the Council of the League of Nations had assumed Jurisdiction over the dispute upon China's request on Septomber 21. Although opposing an investigation th this time, the United States decided that the Logrue was the best vehicl for bringing about a settlement along the lines considered most desirable. On September 24 secretery stimson sent a note to the League expressing the willingness of the

13 The Consul General at Nanking to the Secretary of State, September 27, 1931 - The Foreign Felations of the Jnited States, The Far Esst, 1931, III, 80

14 stimson, op. eit.s. p. 44 
United states to cooperate. $15^{(32)}$ It was his hope at this time thet proseure from the League, of which both Chine and Japan were mombers, would bring about the conference between the two disputants that would settle the 1saue.

Thus the United States preferred the use of this organization which it had refused to join and in which it had show a lack of confldence. In now turning to the weague, Washington 111ustrated growling awareness of the League and 1ts potentialities. Stimeon argued that it wag gound judgment for the United Stetes to back the International organization rather than assume leadership in this case, alnce it would now appear to bo Japan $\nabla$. the world sather than Japan v. the United ctates. Further, StImson contended that alnce the Leegue had already assumed jurledietion and had all the mechanism for settling alsputes at 1 ts alsposel, the United states would have no justification at all in ans other coureo of action. 16

Desplte this American position, the Ieague ras handicapped throughout the orisis by 1 ts doubt as to the extent to which the United states would cooperate. Thero seems to be I1ttlo question that the American conoeption of cooperation and whet the League had hoped for were not the eame. In The Manchurian Crials, Sara Smith eritielsos stimaon contierably for the rather rearved approdeh toward cooperation taken by the Stato Department. M18s Smith contends that

$$
\begin{aligned}
& 15 \text { Ib1a., p. } 46 \\
& 16 \text { Ib1a., p. } 40
\end{aligned}
$$


(33)

Amorlean cooperation with the league hould have been carried out to the fullost extent. This witer agrees that if the Unitad stateg rere determing to rolJ upon the League, 1 t whould hare granted that organization 1ts comple to apport. Th1: was not stingon's polley, howerer. A careful study of his note to the league on 0etober 5 makes it obvlous that the League could not depend upon the United states. The secretary stated in this note that the Onlted states would act Independently through its diplomatio roprosentative to relnforee Loague ection.17 Momwile, al though profosalng to be relyIng upon the Lohgue mochanlsw, Stimeon sont two onvoy, 5. Lawrence Sallabury and George 0. Hanson, to Henchurla to bring boek information. 18 This was not on investigation and In fact mot of th Japan's approval; novorthelose, it was apparont to the Inegre that Amoricen upport at this time might be no different from 1te previou record of non-cooperation, Obviously, stimoon did not mon to croate this impression, but the Loague had good raason to be suppleloue of the motives of the United States towerd 1t, and on exproselon of Independent action this time could do nothing but enbance that fooling. There is no question that concluaive aetion depended upon Amoricen support, and because of th1s the Leagre moved with extreme eaution.

17 Bisoon. T. A., Amertean Pollor in the Fas Fest (Now Iork: International Seoretarial Institute of Pac1fic Relations, 1939), p. 22 
This contention is trengthened by the fact that the League's first official action met with no American comment. 19 On september 30 the Counc1l, expressing conviction that Chine would protect the lives and property of Japanese National and that Japan had no territorial ambitions in Manchuria, formally requested that both parties do all in their power to restore normal relations. 20 This would have been the time for a positive statement of support by the Onited stater. It is true that this action by the League was not of much signiflcance; nevertheless, positive support rather then the note implying independent acti on would have given the League much needed feeling of confidence in American cooperation.

Despite the uncertainty of the American position, the lull in military activity prompted growing optimian that a peaceful solution might be realized. This foeling recoived a mude jolt on Detober 8, however, when Japenese planes bambed the clty of Chinchow. Chinchow, located more than 100 miles southwest of Mukden and at no place closer than 50 milos from the South Manchuria Rallway, had recently become the temporary capital of Chang Haueh-liang. 21 The Japaneso clalmed their planes were on military reconnalssance mission, since Chinese troops were concentrated at Chinchow, and dropped

19 Smith, op. c1t., p. 73

20 The Verdict of the League, China and Japan in Manchuris, The Report of the Assembiy (Boston: The World Peace Foundation, 1933), p. 28

21 smith, op. oft., p. 83 
bombs only after belng fired upon. 22

The nations of the world did not secept the Iapanese explention and vere choked by the dostmotion of civilian property and the killine of women and children as well as of w111tary personnel. The bombing had oowe within forty-01ght hours of the tIme Japen had announced it would no longer recogal ze the suthority of Chang Hsueb-liang and had aropped loaflets referping to the Manchurien leador as "stinking, sapre1 ous jouth. $n 23$

The offleial reaction of Baron Shidehara and the Japanese Forelgn office was that the boubing was an isolated Inoldent of no real importance to the solution of the Manchurian probien. 24 Seeretary Stimson immodiately in- trueted the Oharge' a 'affaires in Japan to 1 sue protect to Baron Shidehara. This protest, however, was not mado public. Stimson was stil atriving to llow shldehara to gain control of the 1tuntion, and as far as the Anertean public wes concomed, the ChInohew bombing had caused no serlous concern In the state Department,

It is obrlous the offleial American attitude wae beglnning to change. The Japanose Forolgn office was informod

22 The Charge' in Japan to the sooretary of state. Detober 10, 1931 - The Foreign Relations of the Unitod Steter. Jepen. 1931-1041, I, 16

23 Smith, op. alt.. p. 83

24 Menorendum of Under soeretery of state castlo, Oetober 12. 1931 - The Forelga Relations of the United Stated. The For East, 1932, III, 165 
(36)

that the bombing could not be minimized nor consldered unImportant. Chinehow was more than 50 miles from the South Manohurie Rallway and the Chinese had every right to concentrate troops thore. Furthormore, the protent contimed, the United stato conuldered the bombing of olties and elvilians to bo completely unjustifled and the Jepanese explenetion of the luation inadequate. 25

Shldehare Imediately roplied to stimson that he ald not moan to mininixo the incldent, but it wa: on 18010ted military action and ald not represent the real attitude of the Japanese government. 26 Upon reflection, this statement almost seon: 11ke on admission by Shldohara that the Japenose goverrmont was losing rather than gaining control of the situetion.

Amazing it may seow, Secretary Stimson nover discussed the Manchurian stuation with Presldent Hoover unt12 after the bombing of Chinchow. Unquestionebly, the reason was that hoorer was too prooccupled wth tho Amorican finoncial erists; yot throe wook is far too long time for the state Department to be conduating a mojor polley without prea1dentlal consultation. At this time, howerer, the Prosident ggreed of th stimson the the United state should oft jointiy wth the league in the forthooming disoussions as long as they centered around the Kellogg Pact. Hoover wa convinced

25 The seeretary of State to the Charge in Japan, October 13, 1931 - The Foreign Relations of the United Stater. Japen, 1931-1041, I, 20

26 monorendum of the secretary of state, Oetober 12 , 1931 - Ibld.. pp. 22-23 
the Kellogg Pact would bo a loss of fensive instrument to Japen than the Nine Power Treaty. 27 As has been seon, this was the opposite view from that of Stimson who favorod the use of the latter document. The re is no question that Stimson wa beginning to consider atronger policy this time but was still a long way from ing any decided change. This slowness was primarily due to stimson's determination to carry out his inftial pollcy, but the cautious Hoover also contributed to this delay. The fact that Hoover did oxert Influence upon the secretary is evidenced by the acceptance by the latter of the Kellogg Pact approach.

On October 16 the United States accopted the Invitetion of the Leagre to send a delegate to sit in with the Council dellberating upon the manchurf an erisis. Prentis B. Gilbert, the Conoul in Geneva, was instructed to particlpate only in discussions which involvod the Kellogg Pact. 28 Meny in the United Stetes supported the decision to send representative to the League, but many 1solationists were just a vehemently opposed. The powerful Hearst nevgpepers used the headine "Heaven Help Us" to describo the move and indicated that war would be its most likely result. 29

The Japenese violently opposed this conference of the Counc1l and in particular the docision to Invite the United States to particlpate without the consent of both parties to

$$
\begin{aligned}
& 27 \text { Smith, op. olt., p. } 86 \\
& 28 \text { Stimson, op. ait., p. } 63 \\
& 29 \text { Tupper and McReynolds, op. cit., p. } 299
\end{aligned}
$$


the dispute. The powerful General Minami declared, "The fundamental policy of Japan to seok settlement of the Manchurien affair through direct nogotiations cannot be modifled... . No good can be accomplished by the intervention of the League or any third party possesses no knowledge of the situat1on." 30

Despite Japon's objections, Gilbert sat in on the conference, whose first official act wes to request ell of Its mombers to send independent notes to Chins and Japan callIng attention to their obligations under the Kellogg Pact. The United states was in agreement with this more and sent its notes to both powers on 0ctober 20. Immediately following the sending of these notes, however, G1lbert was taken off the commission. 31 There is no doubt thet the Japanese objections to American participation in the conference worriod the State Dopartmont, and Glibert was withdram in en offort to avold ony further complications with the Japanese, who were still boing coddled in an offort to onhance Shidehara's Iiberal position. As far as the Leaguo was concerned, the removel of Gilbert was another indication that it could not rely upon American support.

The action of the Counc1l wa ellmaxed on October 24 with the proposal of resolution which called upon the Japanese to wthdraw the1r troops back into the rallroad zone by noveriber 16 and for the Chinese to make arrangements for

30 Takeuch1, op. e1t., p. 359

31 stimson, op. elt., p. 66 


\section{(39)}

retaking the proposed evacuated territory provided full protection was accorded to Japanose property and 11ves. The resolution also provided for direct negotletione between the two Alsputants once the Japanese withdrawal was completed. 32 Resolutions of the Counc1l, under Artiole eleven, however, neoded unanimous approval inoluding that of the disputents, and this ane failed to get it because Japan, a Counell member, would not give its consent. In rejecting the resolut1on, the Japanese stated that they would not w thdraw their troop and would accopt joint Japanese-Chinese oonference, only if it were based on certain fundemental points. The Japanese otipulations were that both countries repudiate aggresafe policy, that Chinats territorial integrity be respeted, that all morements interfering with rroedon of trade be suppreseed, that all poacerul pursults of Japanese nationais in Menchuria be protected, and that complete respect be given to all Japanese treaty rights In Menchurla. It must be aded, howevar, thet at the time of the rejection of the Counc1I's resolution Japan was not interastod in a solution even on these desirable terms. This is indioated by the fact that wh1le the Council was in sesulon the Japenese spoke of Pive fundamental points but did not make ther public unt1I after the coune1l had adjourned. 33

This proposal and the mannor in wioh it was prosented after the Council had adourned were an open deflance

32 The Verdict of the League, Chine and Japan in Manchur1e, op.elt.. p. 31

33 stimson, op. elt., p. 68 
(40)

of the League by Japan. Obviously such attlement would have oliminated the chinese boycott and completely establiahed Japanese domination of Menchuris. The degres to which Arartean unw1111ngness to go along if th the Iergue encouraged this Japaneso position is uneortain. There sems to be no doubt, however, that it did play a part. It is posalble that Japan would heve defled the Loague regardless of the Ameriean pos1t1on, but it is coubtful that ahe would have done so ar quidk J and with such boldness.

The United States indleated that it would probably not support any foreeful Loague aetion by sending allbert as its onvoy. Hugh 01baon, the Ambasader to Bolgiun, and Hugh W11*on, the inister to switzorland, were both of greater alplonatie rank and Influence than Glibert, and both were aveliable and wiling to attend. 34 It is obvious thet the United stated wanted to avold serlous ontanglements, so it went one of the lesser members of its diplomatio family. As if this wero not evidonoe enough, the attitude of the United states wa made conolusive by the wharewal of Gilbert before the council adopted 1 ta resolution.

One explention of this cautious polley 110 s in definite conflict of attitudes with the state Dopartment. There were some, 11ke the chlef of the Far Eastern D1vision, S. K. Hornbeck, who were definitely pro-Chinese. Howerer, the greatest influence in the depertment was exexted by W. R. Castle, former Ambasador to Japan and an acknow 1- 
(41)

odged sympathizer with that country. A wook after the inftial clash at Mukden, Castle had aserted after a conversation with Ambassador Debuch1 that it was obvious that the Premier and Shidehara were regalning control and settlement wa inminent. 35 It is known now that this was definitely not the case. Fur thermore, Castle was known to be a close personal friend of the President, a fact which contributed to his influence.

The inftial, very cautious policy of the United States was deslgned, therefore, not to entegonize Japan but to evold any positive action. President Hoover and secretary stimson, as has been shown, were influenced appreciably by Undersecretary castle, and were convinced that any definite action might be disatrous. They were partlcularly concerned that the League Counc1 $1 \mathrm{mlght}$ resort to economic sanctions, move which was wi thin the power of that organization. There is no question that it was the fear of boing inolved in suah step that prompted the removal of Gllbert from the Counc1l discussions. The American le aders felt that economic senction would be terrible blow to our sagging economy and might even precipitate war. The depression, the weakened position of the navy in the Pacific due to the Wahington and London Conferences, Hoover's Quaker background, and trong isolati onist sentiment in this country precluded any policy that might even remotely threaten war.

35 Memorandum of Under Secretary Castle, September 25. 1931 - The Foreign Relati ons of the United States, The Far Esat, 1931, III, 67 
(42)

Thus, Japan was ellowed to consolidate her gains in Manchuria with nothing more than an expression of the world's concern. The United States showed that 1t wes foarful of the consequences of opposing Japm, and our policy seemed only to encourage her to further aggresiton. 


\section{Nanchuria in 1931}

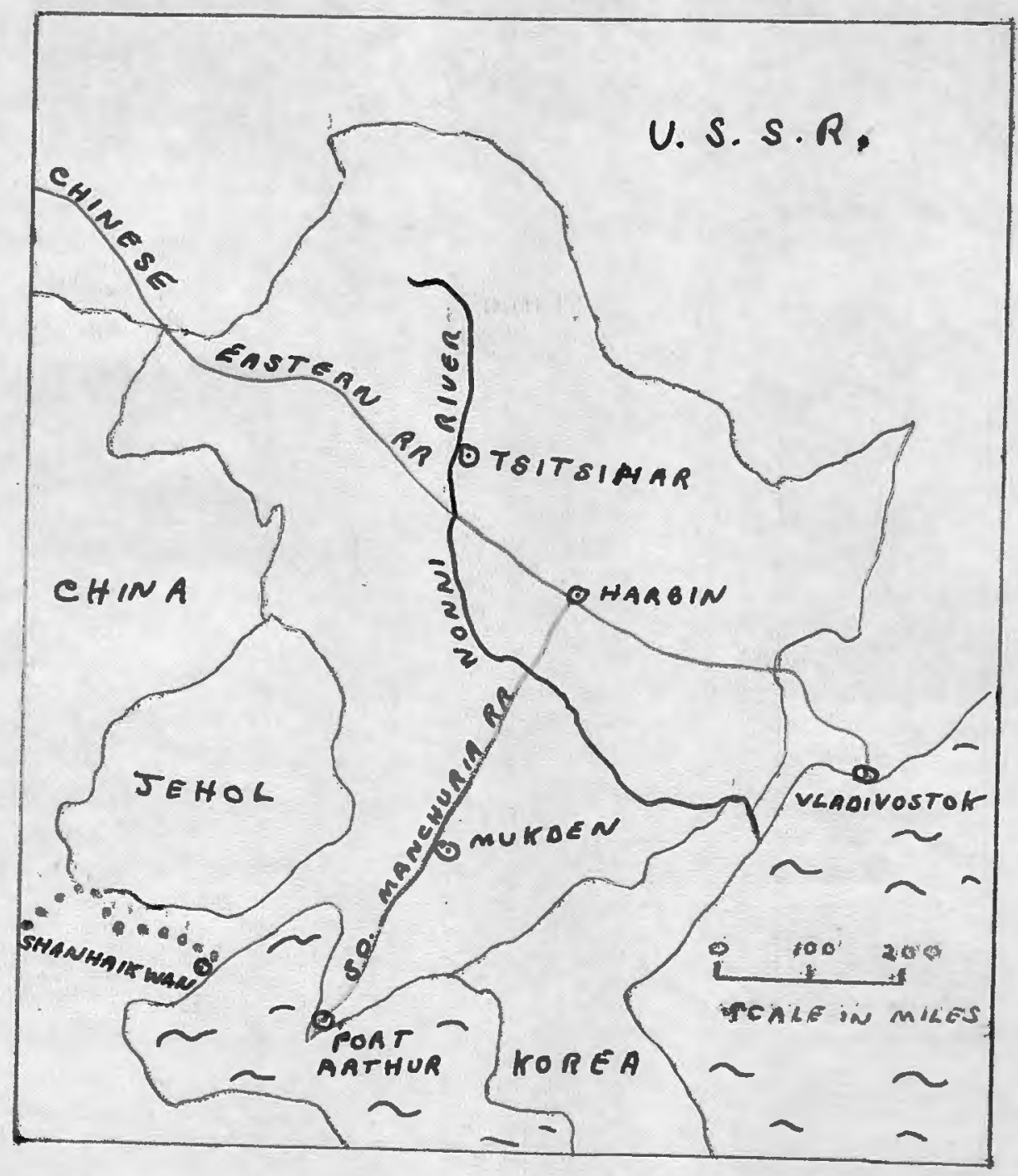

Pigure 2 
THE STIMSON DOCTRINE

Although it rejected the League resolution of October 24, the Japenese government claimed that it did not intend to expand the Manchurian conflict. Th1s promise was broken in early November, however, with the attack upon Tsitsiher, the capital of Hellungkiang, Manchuriat nothernmost province. 1

An internal atruggle between two Chinese leaders in northern Manchurie had resulted in the destruction of railroad bridge over the Nonni River. The bridge wa located thirty miles south of the junction of the Chinese Eastern and Taonan-Anganch1 Railroads; its destruction interfered with the flow of traffic including much needed food to the south Manchuria Railway. Japanese authorities of the latter line demanded the bxidge be repel red immodately. When no assurance of such action was given by the Chinose, Japanese laborers, accompenied by military troops, were sent to put the bridge back into operation. On Novembor 4 the Japenese force arrived at the Nonni River and cleshed with Chinese troops in the area. By November 6 the Japanese had gat ned control of the river and repair work had begun. 2

Stimson, op. cit., p. 70

2 Smith, op. att., pp. 129-30 
When confronted by secretary stims on with a query ebout the new outbreak, the Japanese Ambassador asserted that the troops were only to be used to protect the reconstruction of the bridge, and there was abolutely no intenti on to launch an offensive from the Nonn1 River. ${ }^{3}$ As usual, however, this was the promise of the Japanese government not the militery. General Honjo, the military commender in Manchuria, had orders from Tokyo not to pags a line fifty miles southeast of Tsitsihar. The general ignored these instructions, however, and 1 sued an ultimatum to the Chinese leader in the region, General Ma Chen-shun, demanding that he evacuate his capital. Whon the ultimatum was rejected, General Honjo launched an attack on Tsitsihar and captured the efty on November 19.4 A a result of this breach of faith by the Japanese Secretery Stimson rooognized that his policy of conclilition was not going to $w$ orik and that a more positive stand must be taken. Another factor unquestionably contributing to this feeling was a telegram from Ambassador Forbes, received the day before Tsitsihor fell, wich acknowledged that rumors were strong in Japan that the conservative government, whom the State Department had tried so hard to assist, was about to $\operatorname{rall} .5$

On November 21 Stimgon gain called in the Japaneso

$$
\begin{aligned}
& 3 \text { stimson, op. c1t., p. } 70 \\
& 4 \text { smith, op. c1t., p. } 131 \\
& 5 \text { The Ambassador in Japan to the secretary of state, }
\end{aligned}
$$
November 18, 1931 - The Forelgn Relations of the United States, The Fer East, 1931. III, 474 
Ambassador who assured him that the troops would be withdrawn from Tsitsihar as soon as possible and that his government wa now willing to consent to neutral investigation. 6 for the first time, Stimson did not eccept the Japanese government's assurances and declared that the United States considered the attack upon Tgitalhar a direct violation of the multilateral peace treaties, and that horearter all deliberations between the United States and Japan would be made public.? Thus, a milestone in American polley was reached. Ho longer would the State Dopartmont keop 1ts negotiations with Japan secret and attempt to make the American publ10 regard the stuation a minor incident that oould oasily bo put under control by the Japanese government. At last Washington was aware that the military was in complete control. The oxcessive care that had been taken not to ombarrass the liberal civilian eloment in the goverament had the opposite result from that intended. The American hand of poliey had not helped the government but had given the military chance to gain complete dominence. It was now obvious to the stete Department that to continue the present policy would be futile. There can be no question that Stimson's move was wise one, but it undoubtedly would have been more effective

6 Memorendum of the Secretary of State, Horember 21, 1931 - The Foreign Relations of the United States, Japan. $1931-1941, I, 46$

7 Memorandum of a telephone convergation between the Secretary of State and the Secretary General in Geneva, November 21, 1931 - The Forelgn Relations of the United States, The For East, 1931. III, 515-23 
had it been made sooner. The Japanese were now becoming extremely ambitious, in large part due to the encouragement given to them by the cautious American policy. Reports were beginning to come in that they were now eying Chinchow. Chang Hsueh-118ng had etablished thig city in the south as his capital, and it represented the last stronghold of the Chinese north of the Great Wall. Control of Chinchow mant complete domination of Manohuria for the Japanese. The reports were that the were bullding up supplies and troops near the city, and General Honjo was threatening to attack if Chang Hsueh-liang did not evacuate. 8

Again Secretary Stimson called in the Japanese Ambassador, but this time he did not seok any assurance. The Ambassador was informed that the United states considered the Chinese forces in the Chinchow no match for the Japanese, end that the latter were in no danger of attack. Further, the American government could see no justiflcation or excuse for an ottack on Chinchow, and if it occurred it could bo considered nothing but an act of aggression.9

As expected, the Japanese Ambassador Implied that there was no need for American concern, but by this time his assertion merited little regard. The American military attaché in Tokyo, Colonel MoIlroy, had been sent to Manchuria and confirmed that the Japanese wore making military propara-

8

Smith, op. c1t., p. 188

9 Memorendum of the secretary of State, November 22, 1931 - The Forelgn Relations of the United States. The Far East, 1931, III, 534-35 
(48)

tions almed at Chinchow. The Colonel informed the State Department that the assurances of the Japanese goverment were meaningless since the army, not the cabinet, was determining policy in Manchurs.$^{10} \mathrm{Also}$, a report from the Minister in China indicated that the Japanese intended to destroy the final power of Chang Hsueh-1lang in order to proteot a probable united puppet govermment in Manchuria. 11 In late october nominel municipal and provincial governments had been orgenized ond in large part edminfatered by the Japanese. Th1s fact seemed to be a forerunner of a new Japknese-dominated government for Menchurla which rould not be able to exist unless all Chinese authority in the orea wa eliminated. 12 Largely due to the protest of secretary stimson and also similar ones from the British and French Forelgn Offices, the Japanese called off the impending operation at Chinohow. This halt only proved to be temporary, however, and came after a misunderstanding of some remarks by Stims on which nearly rosulted in serious consequences. An Associated Press report in Japan of a press conference quoted the secretary s saying thet the Japanese olaimed to be only protecting their interests and repeatedly had given assurances that they would make no aggressive moves. Yet, they had attacked one city after another. The report indicated further that stims on had atated

10 The Assistant Military Attache in Japen to the Adjutant Genere1. Horember 28, 1931 - Ib1d., p. 582

11 The Minister in Ching to the Secretary of state, November 26,1931 - Ib1d., p. 569

12 stimson, ㅇp. cit., p. 192 
(49)

he was losing patience with the Japanese and warned that an attack on Chinchow would destroy entirely the peaceful negotiations now taking place.13

The Japanese press made conslderable copy of Stimson's remarks and provoked bitter public denunclation of the Secretary and the United States. It also ralsed storn egainst Baron Shidehare who wa accused of revealing milltary secrets in essuring stimson there would be no attack upon Chinchow. 14

StImson, through Ambessador Forbes, dented the press version of his remarks. He stated be had simply been informed by press dispatehes of an impending attack and hed expressed hls hope to the Japenese Ambassedor that there was no basis for such reports. 15 It is obvious that stimson did not make the statements attributed to him by the press, but it is also evident, as has been shown, that his talk wi th the Ambassador was a great deal stronger than he was willing to admit publiely. Baron Shidehara vigorously denied ho had given away military secrets, and the controversy died almost as quickly as it had boen born.

The siturtion quieted because Japan had decided to

13 The Ambsesador in Japen to the Secretary of Stato, Hovember 28, 1931 - The Forelgn Relations of the United states, Japan, 1931-1941, I, 51-52

14 Takeuchi, op. cit., p. 367

15 The Secretary of State to the Ambassador in Japan, November 28, 1931 - The Forelgn Relations of the United States, Jopan. 1931-1941, I, 53 
(50)

follow now course In regard to the League and had callod a halt to the Chinehow operation. Whis set might seom to be an indication that the government was regaining control, but such va: not the ease. The Japanese had almost completely oolidified thelr position in Manchuria and wore now ouggesting that on Investigating coumission be estublished. This course was adroented in order to prerent punitive eetion by the Loegue. Brit1ih, Fronch, and Amorlean protoste over the pos1b1. attack upon Chinchon had Ind1oated to the Japanose that a continution of the operation might reault in the League taking unfaverablo acti on againgt thom. An invertigation would give the Japenose time to oomplete tholf dominntion of Manchur1a, wile punftive weti on at this point might undo all the mllitary had aecompli ahed. 16

With Japan now adroouting polley almost completely contrary to hor original one, the Counall of the League reconvened In Faris on Hovember 16. Once more the Unitod states docidod to send a representative to the procesdings, this timo selecting Charles 0. Dawes, the Ambsesador to London. Wuch oriti ol an had been raleed ores the releotion of Dawes. Despite the prominonoe of the rormer Viee-Presidont, his diplematio exporionec for such task was quostionable. Also, his friendsip with the Japanse Ambassedor to London, Tsunoo uatsudalre, has brought secusations that he was pro-japanese. In light of

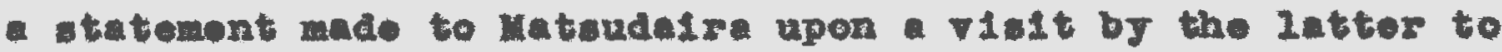
his hotel oulte, there soeme to be some justifloation for this 


\section{(51)}

v1ew. At this time Dawes declared: "The Chinese are altogether too cocky. What you poople noed to do is give them a thoroughly good licking to teach them their place and then they wil be willing to talk sense." 17 The biggest criticlem of Dawes, however, wos the fact that he stayed away from the council moetings and conducted al his business in his hotel sulte. This unavallability of the Ame ric on representative again raised the doubts omo the League powers as to just what extent they could depend upon the support of the United Stetas. 18

Despite the uncertainty of the American position, the Councll accepted the Japanese proposal; by a resoluti on of December 10 it establishod noutral comnission of inquiry. This comission, when formed, conelsted of the Eerl of Lytton representing England as chalmen, General Henri claudel of France, Count Aldrovandie-Marescotti of Italy, Dr. Heinrich Sohnee of Germany, and Major General Frank MoCoy of the Unfted States. It's mabers were responsiblo to the League, not to their individual countries; it was to go to Manchurla to ascertain the facts and prosent them to the League for ad judication. 19

The United States was very much in favor of the resolution of December 10, which also ineluded promise by Japan

17 Ferroll, Robert H., American Diplomact in the Groat Depression (New Haven: Yale University Press, 1957), p. 146

18 smith, op. olt., p. 161

19 stimson, op. e1t., p. 206 
to refrain from further hostilities. Secretary stimson expressod his approval in a note to the League sent immediately upon the adoption of the resolution and also allowed General McCoy to perticipate in the inquiry. 20

The creation of the Lytton Comission did not represent as significant a step as many belleved. The initial clash was already three month in the past, and by the time the commission was able to organize and get to Manchuria, the evidence was no longer fresh. Fur thermore, the investigation had not come unt1l Japan wa ready for $1 t$, and 1t now served that country's aggressive ambitions. While the United states and the League awaited the findings of the Lytton Commision, the Japanose were granted the time necossary to make their doninetion of Manchuris complote. As a consequence the resoluti on and the creation of the Lytton Comiosion ended in promoting rather than hindering Japan's designs.

On Docember 11, the dey following tho establishment of the Commision, the Minselto cabinet fell from power. There has been some dispute to the cause of this rall. Sara smith, for instance, states that the fundamental cause was the inability of the government to moet the financial crisis. 21 More likely, however, is the contenti on of Tatsuj1 Takouch1, in his excellent study War and Diplomaor in the Japanose Empire, that on internal atruggle within the Minseito Party over its handling of the Manchurian question

20 Report of the League Assembly, op. c1t., p. 38 21 smith, op. c1t., p. 51 
(53)

was the major cause of the cabinet's resignation rather than 1ts finanolal program. 22 At any rate, the government foll, and on December 13 now cablnat was formed by the rival selguka1 Perty with Takeahl Inukal as premier and Konkichl Yowhisara as forelgn minlster. 23

The new government proved to be much more sympathet10 to the ldeas of tho miltery leader than 1ta prodecessor. At a moting hold on Docember 17 the cabinet accepted the request of the new War Minister, General Sadeo Arakal, to send relnforcements to the Chinohow area to assiat in the drive against Chlnese bandits. The Japanose contonded that the Chinese had broken tholr word by not ovacuating the 1r troops from Chinohow and were unable to oontrol bandits running wild In the area. 24 Colonel MoIlroy, the American military observer in Hanchuria, conflrmed the now bulid up of Jepanese troops, roporting that m111tary headquarters in Mulden had informed him that the purpose was to put down Chinose bandits, and there was no Intention of taking Chinchow if the Chinese troops were withdrawn. The Colonel doubted, however, the Japanese would not go all the way. 25

Colonel HeIlroy proved to be wive prophot. The alleged operation agalnst Chlnese bendita began on December

22 Takeuchi, op. a1t.. pp. 365-66

23 Ib1d., p. 361

24 Ibld., p. 369

25 The Milltery Attache' in Japan to the Adjutant Genere1 - The Forelgn Belations of the United States. The Far East, 1931, III, 689 
(54)

23, and one woek later, wh Japenese forces attacking the outsicirts of Chinchow, the wi thdrawal of the Chinese troops in the city began. By Januery 3 all the Chinese troops were out of the elty, and the Japanose occupation of chinchow had been officielly accomplished. The Japanese then proceoded to make contact with their troops atalioned at Shanhalkwan, just south of the Great Wall. With this Chinese authority completely disappeared from southern Manchuria. 26

The military events following the fall of the Minselto Cabinet were regarded with grave concern by the Amerlcan state Department. Socretary stimson, a mentioned, had given up hope of helping the Japanese government find its own solution after the fall of Tsitsihar and the inftiel movement upon Chinchow. St11l, there had been no definite statement of American policy. Stimson now reelized, with these now developments, thet the Inited states could no longer appear disinterested and that def'inite statement of polioy mas necessary.

Two days before he me offleial pronouncement, Secretary stimson explained in departmental memorandum the reasons for the need of a change in pollcy. He stated that in severel Instances Japan had used military force to obtain natIonal objectives and $w a 8$, therefore, violating the Kellogg Pact. Further, the secretary contended that desplte the absence of any formal resistance by Chinese troops, the Japanese had destroyed the adminlstrative integrity of the government

\section{The Report of the League Assembly, op. alt.,} pp. $39-40$ 


\section{(55)}

of China in Manchuria. The Japanese had broken a solemn promise, made in the Councli of the League on December 10, to refrain from any new initiative which would rogult in 108 of Iffe and to keep only enough troops in Manchurfe to protect the South Manchuris Rallay. Stimson concluded that the attack on Chinchow was a definite brech of this promise and called for positire action by the United States. 27

Stimgon called in the Jepanese Ambasador prior to deIlvering the note Informing him that while the United states was roserving final judgment untli it had seen the report of the Commision of Enquiry. the complexity of the siturtion required that a atement of policy be mede. He ind cated to the Ambasador that the Insted Statea had no quarrel wi th Jepen's rights in Manchurja nor did it have any dosiro to intrude upon the terms of a final nettjemont which might be rade between the tro disputent countries, es long as that settlement did not impair Amerjem if ghts in Chine. Further, the secretary made it plain that no settlenent which had been made under military prosaure and in violation of the Rellogi Pact would be recognized. 28

The note 1tself, sont to China and al the gignere of the Nine Power Pact a weIl a Japan, was delivered on January 7, although ectualy drafted two deyg onrlier. The

27 Memorandum of the Secretary of State, January 5 , 1952 - The Forelgn Relations of the United stetes, The Fer East. 1932, III (Washington: The United States Govemment Printing office, 1948) 5

28 Memorandum of the Secretary of state, January 7. 1932 - Ib1d. 8 
Stimson Doetrine, at this tromendoubly significant step in

Amerioen polley oame to be called, stated?

W1 th the reeent military operations about Chinchow, the last rondining admini trative authority of the governmont of the Ohinose Ropubilo in South Manohuria, it exfinted prior to sept. 18th, 1931, has been destroyed. The American goverment continues confident that the work of the aoutral combialon recentis authorlsed by the Couns 11 of the League of Hation 1121 fac1l1tate an ultiveto solution of the diffioultios now existing botwoen Culna and Japan. But in view of the present ituation and of 1 te orn rights and obligations therela, the Americen govermont doeng it to bo ita duty to motify both the gorerment of the Chinese Repubile and the Inporial Japanose governaent that it eannot adnit the legallty of any ituation de facte nor doos it intend to reeognize any treaty or agreomont antered into between those gorerments, or agents thereor, which nay impair the treaty 11 ghts of the United states of Ite cltizene in China, ineluding those whioh relato to the verorignty. the indepondence, or the termt torial and administrative integrity of the Repubile of China, or to the Internati onal polloy relative to China, comoniy knom as the open door poliej and that it does not intend to reoognize any litution treaty or agroement vileh way bo brought about by monns contrary to the covonants and ob11gations of the Pact of Paris of August 27, 1928 to which Treaty both Chigh and Jepan, as well as the OnIted states, aro partios.29

This atatement of Amoritoan polley represented the strongont pronounoenont mude by any nution, outside of Chink, Ince the orials had begun in september. Chine, onoouraged by the atrength of the Amerlean otand and foellng that the League's offorts were heading for fallure, agaln began to pres: for postive punitive action by the Onitod states agalnot Japan. The Chinese hoped that ou action oould be conleved through a conference of the al gnors of the Hino Power Preaty, but the United states felt that we a more

29 Memorandun of the seorotery of state, Junumy 5, 1932 - Ib1d.. 8 
would be Inadvisable at that time.30 The stimson Doctrine did not represent a complote condomnation of Japan, and it is obvi ous that the United states was not jot ready to attompt such a stand. The adminfetration wanted to avold any polley that might war-11ke, partieulariy th on oleetion eomIng up and alrokdy booring as it did the brunt of the blamo for the finencial exis1s. Furthormore, the disappointing rocotion of the Europen powers to the StImeon Doctrine Influonoed the State Dopartmont grently in 1 ts unillingness to go ang farther than this modorate exertion of moral prosure. Socrotary Stimson had requested in his notes of January 7 that all of the al gnors of the IIn Power Paet draft pronouncements similar to his own. He was of the opinlon that a multi-nation atatomont would be far more offoetive than that of just one porrex. Thore is no question that he was correct In his ascumption, but although som of maller powors supported the polley, the major powore ill considered it too trong. 32

stimson was partieularly hopeful that the Britiah would Join him in his pronounerement and in The Fax Eantern Cx1sis states that there was no reason to bollore that they would not. 32 The Labor gorornment of Remaey MaeDonald hed participated in sereral International conforences of the the

30 Memorendum of the Ghief of the Division of Far Esatern Affelrs Hornboek, Jenuary 8, 1932 - Tb1d., 10

31 stimson, ㅇ․ elt.. p. 98

32 stimon, or. alt.. p. 100 
United states, and both countries had resolved to direct natlonal polley toward fulfliling the pledge of the Pact of Per1s. Bren though HacDonald's government had been defented In 0etober of 1931, the now Coalition gorexment had given no indieation that it intendod to follow anj polloy other than contimuing this cooperation. Movertheless, when put to the test, the now British government opened the door of appeasement to Japen and would not go long with the Amorloun pol10y. 33

S1r John S1mon, the head of the British Foreign Orflce, replied to the Ameriean request that his government aeceptod Japen's tatement of Dotober 13, 1931, that whe was the chanplon of the opon door in China. Furthermore, on December 28 the Japmoso Prouler had restated this fact and doclared that his country would continue to adhere to the "open door" and would weloone forelgn participation cooperation in Menohurian enterpr 10es. In view of these asertions, the British declared that they sat no noed to adrese formal note to Japan other than to seok confrmetion of these statemonte. 34

The London Time, in juetirying the Brttish rerasel to 1ssue statement similar to the stimeon Doetrine, reforred to China as unorgantzed tate. Tho Japanese quickly cepltallaed upon this unofflelal viewpoint. In reply to the note

33 sulth, op. est.. p. 235

34 The Charge in Great Britain to the socretary of state, Jaruary 9, 1932 - The Fore1mn Relations of the United Stated. The Par East. 193I, III, 19 
of Jamary 7, the Japonese assorted that they accepted the binding nature of the Hino Power Treaty and the Relloge Paet but dentad that their actions violated those agroements due to the ungettled and alstracted tate of China wich had not been contempleted by the contracting partiea. They further asared the Untted states that they had no torrdtorial aims or mbition in Manchurie but reminded that goverment that the welfare and safoty of that rogion and 1 ts aceesibility for general trade vere matter of deopect interest and oxtraordinary importance to the Japanose people.35

Despite the politeness of the Japinese reply, it wes st111 notice to the Inited states that they Intended to hold on to the galne made In Manohurta. The Japanose public proved to be very wach in favor of thi atand. On Fobruary 20 a genoral alection was hold with this poliey of the governmont the primary 1asue. The result wat on orerwhelming rictory for the cabinet and an endorsement of 1 te apparent doflance of the stimeon Doetrine.36

often, the fallure of stimoon's pronourcement is attributed to the Iack of Buropean and particularly Briti gh eupport. Although it is probablo that Ruropen support would have made the Japtenose more cautious, it is doubtrul that oven of th thls backing the American polley of moderate morel pressure would have been wecesaful at this polnt. The Japanese had gone too far to baok down now and would take their chance of

Takeuch1, op. o1t., p. 371 36 Ib1d.. p. 373 
(60)

ouffering my possible consequences rather than ondure the publis humiliation that rotroat would bring. They hod tasted both militery and diplematio vietery and were now destined to apread tho bittor confilet of th the Chinese Into eren wider areas. 


\section{CHAPTER IV}

\section{THE SHAMGHAI CORFLICH}

There 1a tendeney to conolder the existo in Manchur separately from the orents whloh oocurred in the elty of Shmghal ourly in 1932. The Japunose contended that the two incidenta were not related, but it would be incorroct to accept this position. There were al reunetences which medo the Shanghal incleent somewhat difforent from that in Manchurle, but both wore claghos golng on almost almultaneous15, and both 1molved the same dispatants. It is diffioult to belleve that Japan would have adopted the aggrealve polley that sho did In shanghal had she not been so succesgful, milltar11y and diplomaticaliy, in Manchura. It 1s logical, therefore, that this thay of Amerlean poliey include the shanghal Incldent well the Chinose-Japenose confliet in Henohuria. Shenghel, Chine, one of the world's largest clt1es. hod soveral unique reatures in this period. Looated in the midst of this typleally crowded and cranped oriental city was probably the most modem and comopolitan communty in Aala. This soction was known as the International Settlemont and was inhabited by com 40,000 British, French, Americen, and Japanese oltizen, all busily ongeged in the thriving commerce of this, the economis heart of China. The particularly unusual 
feature of the International Settloment was the political privileges its of tizens enjoyed. The people of the settlement hed definite munlelpal powers for thelr section, including control of 1 ts pollce force and taxation, entirely separate from the Chinese government of the clty proper. Furthermore, In add tion to the police force, the jor nation represented in the settlement stationd troops there to protect their intereste. Ineluded in this group wero some 1,250 Amorion Harines. 1

The basis of the tension that bogan to bulld up betwoen the Japanese oftizens in the Internati onal settlement and the Chinose in the o1ty was the boycott by the latter of Japanose goods Inftiated in the mumer of 1931 as weapon deslgned to decrease that nation's exploitation of the area. This morement was given tromondous Impetas by the Manchurien orisis. As already mentloned, the boyeott was a serere economle blow to Jepan. Hext to the United States, China had beon the greatest purchaser of Japanose goods, and when the bojeott atmak, 1t wa natureliy folt otrongly in this industrial and comeralal enter. 2

Ther 1s no questi on that the Chins se were guilty of some violonce in carrying out the boyoct. This fact, coupled with an ant1-IIppon preas capaign orer the Manchurian er1B1: and the large number of Japanose Marinos stationed in Shangha1, had ralsod mioh antagonism against the Chinese in

\footnotetext{
1 stimson, op. oft., p. 113

2 Ib1d., p. 111
} 
(63)

the Jepanese quarter of the settlement. Th1s resentment reached a climax on January 18, 1932, when five Japanese c1tizens, Including three monks, were attacked in front of a Chinese ractory. All of tho Japare ar imolved in this inc1dent were seriously hurt, and one of the wonks mot his death. The Japanose protested that the laxity of the Chinese police in putting dow previous domonstrations and minor acts of violence had lod to this serlous inoldent, and it was asserted that the chine se government in the of ty would be held fully rosponsible. The letter lamodiately denled responsibility and declared that the whole affair had been occasloned by the lerge number of Japanese Marino stationed in the 1 ty. ${ }^{3}$

The worlous altuation created by the attack on the monks was magnifled two day later when Japanese elt1zens retallated by sotting fire to a Chinese ractory. This act of destruction rearited in a fleres clash between the fifty Japanose responatblo for It and local polloe. Before the battilng was oror, sereral had boen wounded and ane combatant on each al do had boen k11led. 4

Tenefon in the afty now reached a ferer pitah. On January 22 the Japanose sent a landing foree of 500 men supported by one crulser, one alreraft carrier, nd four destrojers into the area to back the 3,000 troops already sta-

3 The Jepenose Embasey to the Depertmont of stete, Fobruery 7. 1932 - The Forelgn Relations of the Onited States. Japan, 1931-1942, I, 186

4 The Coner l General at Shanghal to the Secretary of State, January 20, 1932 - The Forelgn Relationg of the United States, The Par Bast, 1932. III, 40 
tioned in the ofty. 5 soon (64) twelve destrojers jelned this foree, and the chinese found themselves faced with an imposing show of milltery etrength. 6 Backed by this Inereased milltary power, the Japenese Consul General in Shanghal delivered set of demands to the Chlnese Meyor, Wi Tleh-oheng, on Januery 25. Th1s ecomuntque demended that formal apology be delfiered to the Japnnese government, that those reaponalble for the ineldent of January 18 be arrested immediately, that the Chinese pay the hospital b111. and damages of the Japanese oft1zens involved, that the ent1-Japenese movemont be put under control, and I1na11y. that all organizations promoting that movenont be dissolred. 7 In The Far Eastern Crisig, Socrotary Stimson statos that he had hoped that the note of January 7 would have andod disousion on the Chinese-Japanese 1save, but the threat resulting from the Jepanese milltary bulld-up in Shanghal convinced him that he mast do more. He ves aware that if the boyoott ald not bring Jepan to tormo Chine might reaort to war, and war botween Ching and Japen at this time would be d1wastrous to Amerlean trade. On the other hand, Ohina might relegate herself to abservient position to Japan, a tua-

5 The Ambasador in Japen to the secretary of state, Januery 22, 1932 - The Forelen Relations of the United States. The Far East. 1932, III, 49

6 Ib1d.. Jamary $27,1932, p .77$

7 The Consul Oeneral at Shanghal to the Spcretary of state, January 25, 1932 - The Fore $1 \mathrm{gn}$ Relations of the United stetes. The Far East. 1932, III, 58 
tion the United states would consider equally undesirable. The Secretery was also of the bellef that the new threat to Brition trade might load that nation to cooperato on this mattor, and he called in the Britigh Ambasador, who agreod that some action thould be taken. Fnoouraged by this attitude, Stimeon sent a note to Japen expreaning his concom orer the possible ase of the International settlonent as base for hostilo action againut Ching and urged that waximum restraint be used. Yeanmile, the Amerloan ploet in Hawell for menourers wes instracted to remaln in that location in an erfort to quiet the fears of the eltizens of the International settloment and how the Chinese that the United states was aware of the ituation. 8

At Ifrat, the afraip seomed to bo atralghtening 1tself out. Upon recelving the Japenese domands, the Chinose Mayor of Shanghal informad all parties concerned that bo intended to make all possible coneesstons to wold a clak.9 A report from the Consul Genoral in Manking on January 25 atatod that the Japanese had Indleated that the Chinese roply vas satisfectory, and Amoriean of riolals in the area were of the bellef thet the tensions wore lifting and the stuation could be resolved.10

This optimlan proved to bo unwarranted. Fel ther the

8

Stimson, op. a1t., p. 133

9 The Report of the League Assembly, op.a1t., p. 41

10 The Conmul General at Hanking to the secrotary of State, January 25, 1932 - The Fore 1en Relations of the United states, The Far Eart. 1932, III, 60 
Major's reply, the earlier Amelican note, nor the presence of the United state fleet in the Paclfle area had changed the Japanese attitude. The Chinose reply to the Japanese demands had Indieated that the former would accept the first three points but felt that the fourth, controling anti-lippon behavior, would be difficult. After studying this reply, Adniral Kolohl Shlozawe, the commander of the Japanese rorces In the elty, issued warning that unlos a satisfactory repiy was recelved nocesary steps would be taken to protoct Japanese rights and interests. Desplte a repeat of the original chinese asurances, Shlozawa lseued a second warning on January 27 , demanding that ell four polnts be accepted by 6:00 P.M. the followl ng dey.

The residents of the Internationel settlement were now convinced that the Japanese military foreed were serious. At 2:00 P.I. on January 28 meeting of the Muniolpal cound1, which Inoluded Japanose mombers, wat held, and a state of omorgeney was declared. Under wch eondition prearranged systen of defensive post tions for the area had been organized W1th each of the netions roprosented asalgned to definite soetor. With the altuation ready to explode at any minute, tho Chinese Mayor rommally agreed at 4:00 P.ll. to meet the Japanese demunds complotely. An imediate public pronouneoment by the Japanese Consul General termed the reply satisfaetory, and it appeared clakh had beon avelded.

The relief of the poople of the settlement was short lived, however, when soon after midnight there came the ound of gunfire from the Chinese district of Chape1. Although It 
(67)

would seom unnecessary under the elreumstances, Japenese forces, after giving the Chineso offlcial only thirty winutes notice, had begun to more into thelr asigned dofonsive sector at 11 :45 P.M. Part of the Japanese sector was loeated Just outside the sottloment area in the distriet of Chapei. Chinese troops in that area, whom the ofty officlals had not had tim to Inform of the Japunese intention, took the more as an attrek and openod fire. Immodiately the Japanese returned the fire, and the elesh whloh the Chinose had trived so hard to avold had happened.

As woon as he had recelved the nows of the fighting, Admirel shiozewa sent the ont1re complement of Japanese troops Into the battle and at 4:00 A.H. ordered the planes at his disposal to bowb Chape1. By sunrise the ent1ro quarter was in flames from Incendiary bombs, hundreds of clv1l1ens had mot their death, and an estimated 250,000 refugees were pouring Into the International settlement. 11

The bombing of clties became commonplece in World war II. but in 1931 the unwarranted killing of women ond children as well of of miltary personnel came as severo shook. Pub110 opinton in the United states had been mixed and in somo cases disinterested in the Manchurian crisis, but this atroelty In Shanghal realted in elmost unireral concern. Condomnation of the Japanese wes sovere. On February 2 the Ph1ladelphia Inquirer oxprossed the foeling of the Amerion people whon it steted: "The bombing of residential sectlons, the murder of 
(68)

helpless mon, women and chlldren puts Japan boyond the pele of ofvilised warfare."12 Even more voofferous was the New York Defly Mirror wioh declared that the "Arrogance and ruthlesenos characterizing the Japanese naval descent on Shonghal ought not to surprise angbody. Humble and concilietory whon the bajonet is at his own belly, this jollow dwarf, pretending recognition of civilized usage, giver no quarter and ahows no mercy in contrary situation." 13

At the sequest of the British Goremment, which 88 previously mentioned took and alferent view of the Shanghat affair from that of Manchuria, tho United states sont joint protest to Japan. Also, both the British and American Ploets In the Pacific vere sont to the inmediat sceno of the confliet as moans of showlng the concern of those natione. secrotary Stime on lway considered this move as belig instrumental in avarting an all out war. I4 such on asertion, howerer, is queationablo and open to speculation. Cortainly no ovidense, other then stimson's word, substantiates this position.

An Immediate discuselon wes also held botwoon stimson and the Japanese Ambessador. The latter conveyed the explanetion of the attack given by his country's Congul General in shenghal, who raintained that provioug tonsions had thrown the elty Into rrony, and the forces had gono out into the Chapel

12 Tuppor and HeRejnolds, op.elt.. p. 322

13 I01d. pp. 320-21

14 stime on, oe, ait.. p. 240 
district to proteot the 117es of Japanese eltizens in the erea. Upon entering the sector, the Japenese troops were fired upon, and the subsequent attack was simply self-defonse. The Ambassador then promised thet as soon ss the Chinese forces withdrew from the are the 1ssue would be settled. Stimson by this time wes not receptive to any further Japenese clatms of self-defense. He Informed the Ambaseador that it mede no difference if the Chinese hed fired the first ahot. By bringing strong naval foree into shanghal and threatening a landing, Japan had created an oxplosive powder keg, and it was immaterial who applied the match. 15 In The Fer Eastern Cr1a1s, Stimson defonds this viewpoint by ating that the move coming at nigh in secreey and vith ifttlo warning indicated the Japane ve were trJing to make it look as though tho Chinese had atarted the olash. The Secretary states further that shlozawa "was courting suoh olash and wust heve known 1t." 16

The League of Hations atepped into the ploture on January 30 with the appointment by the Councll of an investigating comnise1 on. By the Counc1l resolution of December 10, the League had comitted Itself to an Investigation before pasaing judgment, and it would place itself in an ombarrassing position if it followed any other course here.17 such a process

15 Momorandum of the Socrotary of State, January 30 , 1932 - The Forel gn Relations of the United states, Jepen. $1 9 3 1 - 1 9 \longdiv { 1 1 }, I, 166-68$

16 stimson, op. clt.. p. 123

17 The Report of the League AssemblJ, op. Oft., p. 8 
(70)

would undoubtedy be time-consuming, and erergono lnvolved wanted to bring about a solution soon as posible. Consequently, the ejes of the world began to turn to the onited states for a sotilement.

Public opint on in Japan vas not noariy as trong in 1te support of the milltary's action in Shanghal as it had boen in rogerd to the Manahurian offair. Many Japanese folt that the shenghal IneIdent had unfarorably affootod their standing in world public opinion. Whoreas they felt that they had primary Interesto in Menohurla, other powore had interests Juet as groat, if not groter, in shangha1. 18 In v10w of this, a trece proposed by the Britioh and bropican Consuls was aecopted at 8:00 P.M. on Jamuery 29. The following lay the Japanese sought the good offices of the United states, charging that chines troope had fired upon them the morning arter the truce was accopted, and that Chlang Kal-ohek was concentrating reInforements in Manking. The Japenose roquested that the Unlted Btates use 1 to Influense to provent the Chlnese from oonding reinforcement to shanghal and to persuade them to whdraw their troops already in the elty in order to avold further elashos. 19

It appears that the Jap anese had reallsed they had made serero mistake in provoling this inoldent. They had attecked Shanghal with too small a foree and wen seemingly

28 Takouob1, op. alt.p. 374

19 The Ambassedor in Japan to the secretary of state, January 32,1932 - The Porelen Relations of the United Stated. Jepen, 1931-1941. I, 169 
(71)

repuleed had pesorted to an atrocl ty, the bombing of chapel, whioh shoolred the efvilised world. It was apparent that they now whed to get out of the situation with iltio embarrassment as possible and were hopeful that if the Unitod states cecopted the request for good offlees it might realt in a setisfactory solution.

The Unfted States did aceept and began to work out a settlement. The American efforte wore nearly destroyed on Fobruary 1, however, when Japenese planes, supposedily on a reconnalasanoe misal on, bombed the elty of Hanking. Tho bombIng of thi elty, located two hundred miles up the Yantzo Rivor from shanghal and the aceno of chinese troop concentration, indicated that the Japanese militery officers in the area wore extrenely irreaponable, and atiafectory solution would not be easily achieved. 20

Secretary Stimeon Imedietely called in the Japanese Ambassador again and demanded woh unwarranted operation: as the bombing of Nanking be otopped. Ho asserted that if they were not stopped the Jap wose ould not expect any satisfactory roalts from the Amorican good offices. The Ambasador expresed his deep regret over the ineident and pleced the bleme upon 1rresponsible offleers. At this polnt stimson decided not to press tho issue any further and offered the Ameriean proposal for sottiement. 21

20 stimson, op. e1t. pp. 144-46

21 Hemopendum of the secrotary of state, Pebmary 1 , 1932 - The Forelon Relations of the United Stater. Japen. $1931-1041, I, 173$ 
(72)

The Ameriem proposel, presented with som misgivings after the bombing of lianiring, consisted of the following five points:

1. A cessation of 21 act of violenes by both parties.

2. A halt in moblilzation and preparation for hostilit1ea.

3. A whdrawal by both 1 des from all points of mutuel contact in Shanghal.

4. The ereation of a noutrel sone, polleed by neutral troops, to divide the combetants.

5. Upon ecceptance of these conditions, Japan and Chine would prouptig procesd to settle all out tetending controverales in the apirit of the Pact or Paris and the December 10 resoluti on of the Lengue. 22

The day after the Japenese rocelved the American proposal, Ambessador Porbes talked with Porelgn linieter Yoehlsawa and roported thet the latter was $1111 \mathrm{ng}$ to go along with the firat fous pointe, but the fifth, which obvfously referred to Manchuria, vas considered completely unrelated and unacceptable. The Minister hoped, howoror, that the United states mould consider Japan's accoptance of the flret four pointe as satisfectory. 23 Secretary Stimeon roplied that the United stetes would go along with aettlemont based upon the firat four

22 The seoretary of State to the Ambasedor in Japen, Fobrun 1, 1932 - The Foreign Rolations of the United States. Japan, 1931-1941, 1,174

23 The Ambassador in Japan to the Secretary of state, February 2, 1932 - Io1d.. I, 175 
(73)

points if Japan would agree to consider and not reject the fifth. 24

While the Japanese Gorernment was secking the good offloes of the United States, the milltary wa proparing for posalble resumption of hostilities. Secretary stimson was concerned throughout the properation of the rive point proposel that the Jepanose, dospite their arowed good intentions, would not accopt my solution thet was not a chinese rotreat or humiliation and Japanese vietory. Stimson's villingnes to modify but not eliminate tho firth point did not constitute weh a victory, and on Fobruary 4 the Japenese formally rojectod the Amorican proposal and resumed the host111ties. 25

Forelgn Minl tor Youhlsawe Informed Ambassador Forbes that the Japanese would not have renowed the flgting if assured thet the Chinese would have ceased host1lities, but due to the unrellability of the Chinese in the pat this was not possible. Furthermore, the Ameriem proposel had to be rojoeted on the besis of the fifth point alnoe it was settled Japanose policy not to secept anj noutral partielpation in a sottlement of the Uenchurian queation. 26 The Japanea further ettenpted to justify the rejection of the American proposal in a formal commique to the State Dopartmont. Th1s tatoment

24 Menorandum of the Secrotary of state, Fobruary 2, 1932 - Ibid.. I, 176-77

25 stimoon, o․ cit., p. 250

26 The Ambassador in Japan to the secretary of Stato, Fobruary 4, 1932 - The Fore1 in Relations of the United states. Japan, 1931-1941, I, 180-82 
$(74)$

charged that the Chinese had fired upon Japenese troope after the truce had beon accepted, had contlnued to bulld up reinforeenents, were responsiblo for the whole ineident in the first place. The Japanese folt, the atement continuod, that ther could accept no solution wioh did not place oomplete blamo upon China. 27

The Japanese had now comaltted themelros openis to an gggresa1ve polley in Shanghe1. A Reuters How Agenoy report of Fobruary 8 declared thet the Japanese Forelign orflee no longer gave oven Iip service to the Fine Power Treaty and now favored the serapping of the Open Door and a return to the old poliey of dimembermont. This convinoed socrotary stimson that 1 would be nt1lo to attenpt to reason with the Japanese eny further. Fron this point on, Amoricen polley in shanghal was designed to protect the interests of her citisens Iiving the 28

Throughout the conf11ot, the Internati onal settlement was in great for for 1 to safoty. Its of tizens woro also deeply concerned over the possiblilty of indidents which might bring the United States and the British 1nto the confliet. In en effort to prevent suoh a stuation, the unlted states persuaded the Jepanese, wi th conelderablo diffleulty, to stop usIng the settlement wherf for landing troops. Iren more dangerous was the fact that the Japanese of ten moved troops through the Anerican sector, and there was iwaye the possibility of a

27 The Japmese Bubasay to the Department of state, Februaxy 7. 1932 - Ib1d., PP. 186-88

28 stimson, op. aft.. p. 159 


\section{(75)}

clash with marlno stetionod there. After considerable effort on the part of Anorican offlelals, this practice was also nalted. 29 This represented the extent of Anerican negotiations, horever. Stimson sent a note to Ambasador Porbos ordering him to malo no further effort at conolilations sine It wold only result in mother reburf and humilietion for the United States. 30 American faith In Japan's aineerity was nor ecmpletely ghettered, and a the flghting in Shanghal continued, the state Department began to consider atronger act1 on.

29 yemorandun of the secretery of state, February 15, 1932 - The Forelgn Relations of the United states Jepan. 1931-1941, I, 194

30 The Secretery of state to the Ambarador in Japen. Fobruary 10,1932 - Ibld..p. 191 
CHA PTER $V$

THE DEVELOPMENT OF A COMMOA POLICY

The developments in Shanghel oonvineed Secretary Stimson that som additional step must be token to help the American people better understand tholr country' pollej and to bolster the morale of the Chinose, who were beeoming discouraged by the lack of ald and the fallure of the world powers to take a postive atand. I

Stimoon folt som definite rostaterent of polley was nocessary and hoped 1t could be secompliahod jolntiy by the Igners of the Hino Power Treaty. Prom tho beginning, Stimson hed considered the IIno Power Treaty mo more eppropriate basis for judgmont on the queation then elthor the Kelloge Pact or the Leagre Corenant, because it did not deal in genoralitles ond peofflcally roforrod to china, ${ }^{2}$ It had beon at President Hoover's aggestion that inftialig an attempt was made to 1uvoke the Kellogg Pact. Now, however, the magnltude of the 1 tuation and the fallure of proviou efforts compolled the seoretary to roturn to his original approach.

Two Important factor determined the United States'

1 Stimon, op. eit., p. 98

2 Memorandum of the secrotary of Stato, Pebraary 18, 1932 - The Forelan Relation of the United States. The Far East. 1932. III, 373 
deolsion to make a further positive statement at this point. First, the round table conference at Shangha1, which had been Initiated by the League after the resumption of hostilities, was showng defintte algns of breaking dom. The Enitod States had rofused to take part in this conference ince the Secretary of Stato no longer had any falth in Japan's Incerlty. Also, the secretary reared out lde powers might use the weting to force a settlement of wany tim worn $\mathrm{grlev}$ ances with China due to the Intemational character of shanghe1. 3

Despite this attitude, it is orident that stimeon secrotiy hoped the conforence might be aucceatul in solving the Shanghal question. In a memorandum of Fobruary 18, he stated that ono of tho reasons ho had held off making pronouncement was the fact that the conforeme had looked so encouraging. 4 within fer hours after stimson had prepared th1s momorendum, communique was rocelved from the Hinister In ChIna, Helson Johnson, wich Indeated that the conference was broaking down and any hope for a settlement from that couree wat tat110.5

The other factor influenelng the Secrotary's decision was the creation of the state of Manchukso. As previousiy

3 stiman, op. o1t.. p. 180

4 Momorandum of the secrotary of state, Fobruary 18, 1932 - The Porelop Rolations of the United States. The Far East. 1932, III, 373

5 The Minister in China to the secretary of state, Pobruary 18, 1932 - Ibld.. p. 373 
mentioned, the Japanese had taken the first step in the organization of now state in Manchuria on October 31, 1931. The Japanese conti mualiy referred to these offorts as an independent moventent of the people of Manchurla, but several reports had reached the state Dopartment indieating the Japanese were reaponstble for the movement and were completely bohind $10^{6}$

On Fobruary 18, the same day Stimen received word of the probable breakdow of the Shenghal Conference, the looal governuents of Manchurl jolned together in what was callod the 111 Manehurian Organization and declared thelr Independonce frow China. The following day the new organization deolded to form repubile. The now state was to be known as Manchulcuo, and the holr to the old Manchu dynesty, Henry Pu I1, long since 11ving under Japanese protection, was invited to becom the ohier exocutive.7

stimson's hope was to promote jolnt pronouncement of the Igners of the Hine Power Treaty egalnst both the Shanghe1 attack and the creation of the now atate. The secretery was partialerig mxious to obtein Brition cooperation, just he had been when he delfvered the note of Jamary 7 .

6 The Ambasador in Japan to the secretary of state, January 16, 1932 - The Fore1gn Relation of the United States. Japen, 1931-1941, 1,78

The Minister in China to the secrotary of state, 0ctobor 2, 1931 - The Forelgn Relations of the United States. The Far East, 2931, III, 106 
There was now reason to belleve the Britigh reaction would not be the same as it had been at the timo of the publication of the stimson Doctrine, due to the Allingness of that country to cooperate when the Shanghal situation had first exploded. This asumpti on did not prove to be correct, however, ince the British were mombers of the Loague and wore extremely reluetent to take any action whlle the question was at111 under consideration by that body. After numerous telephone convergation: with S1r John simon, the head of the Brit1ah Forelgn office, Stimson doolded not to press the 1seue any furthor. It was ovident that if the Unitod States wishod to take action at this point, it mast do so alone.8

The problem now was to determine what form the American action should take. A direot note, similar to the one of Jamuary 7, would probably only lead to another robuff. Consequently. Secretery stimson decided to use an old poliey of Theodore Hooserelt, the writing of on open letter. Such a course would make it possiblo to get off an announcenent without contradiction or discusal on. Further, it would not be weakened before being published by the expressed doubt of Influential people.9

It was deolded to writo this open lotter to senator Willim Borah, the chalrman of the Sente Forelgn Relation: Commlttee. Senetor Boreh was an ldenl addressee due to h1s prominent position and due to the known faet he was anti-

\section{8 \\ Bisen, op. e1t.., p. 23 \\ 9 stimmon, op. eit.. p. 165}


(80)

Japanese. At the time of the Mukden Inoldent the senator was quoted as saying, "Even though the Japanese rossons wore ten times as truthrul as it can be assumed they are, there 18 no justifleation for force In Manchuria.... n10

The besis of the lotter was to be the wine Power Treaty, which, as has been sald, who farored by stimon bocause of its specifio roference to Chine. The letter was to bo directed to five unnemed addreaseer. It we to serve as a message of encouragenent to China, an explenation of polloy to the Americen public, suggestion of future possiblo action to the countries no would bo assembled at the next meeting of the League of Nations, end gentle reminder to the British that they were comuthors with the United statea of the Open Door Polley and the Hine Power Poct. Finally, the letter was to serve as a reminder to Japan that if the chose to break down one of the treaties agreed upon st the wasington Conference, cortain nations might fit to reloese themselves from others as vital to Japan as the was to them. 11

Thus, wth the bellef that an open letter would bo as offoctive to the five daressees a a drect note, yot would not beer as many dengers, Seoretery St1uson publiahed the lotter to Senator Borah on Fobruary 23, 1932. The length of the letter precluces its bolng quoted here, but the inport of it does merit rether extensive summery.

10 Tupper and McRejnolds, op. olt.. p. 297 
(81)

The letter began by reaffirming the open Door Polley in Ching. It then went on at some longth to exple in the rine Power Treaty, which the Secretery stated, asured all Interested powers thoir Ifghts in Chino wile 2180 assuring the Chinese people the right to develop unmolested their soverelgnty and Independence.

Stimson continued by declariag that Japan was definite supporter of this troaty at the time it was signod. He substantiated this assertion by quoting Beron Shidehare, who sald at thet tim, "Ho one denies to Chine her sacred right to govern herself. No one tands in the way of Chine to work out her own national desting."12 stimson went on to sey that six jears later the provisions of the fine Power Treaty recolved powerful reinforcement of th the algning of the Kellogg Pact, wioh also included Japan ong 1 ts slgners.

Now dealing with the al tuati on in question, the letter stated that the hostilitios in Manchuria and later shanghol had brought homo the rital importance of falthful observance of both the Nine Power Ireaty and the Kellogg Pact by all nations interested in the Far East. It aserted that the United states felt that if the powers had stuck to the principles adrocated by those covenants, no matter where blame may 110, the host111ties in Manchuria and Shanghai nover would have developed. Also, complinnce wth these covenants would not have interfered with the logltimate rights of ang of the trenty 1 gners. 
It continued wt th aturenat of the note of January 7. whlah advised Chine and Japan that the Unt ted States would resognise no agreement roached by those nations that violatod the Intemational treat1ea. It assortod that this was st111 the pollog of the United states and urged that the othor nathone of the world adopt olnilar stand.13

Final2J, stimson coneluded the letter by teting of the United statoe:

Wo coneur with those stetenen, representing 211 netions in the Wabington conferenee, who declared that Chine was ontitlod to the time nocesenry to aeconplith her dovelopment. Wharo propared to zake that our pollez of the future. $I_{4}$

Thus, the Unlted state hed renfrimed its intenti on not to reoognize anj galns of Jopan aceaplishod through v10lations of the international poace trouties and, al though not dreotiJ coadoning Japen's etton, had brought moral pressure upon thet country. Publ1e oplation 1a the United states ras very much bohlnd this poliej. Loading mewapapers throughout tho country halled the lottor to Senator Borah a a fitting rofolnder to Japan's argmeonts reoling to fustiry the oporations in Manchuria and Shanghat, ther wore almost unanimous In urging the support of the Amoen popie. 25 Furthermore, this polley was not rogardod as colaly bJ the Buropear porers an was the stimson Doctelne, and it became the guide

13 stiagon, gn alt.. Tho Lotter to senator Borah 1. found on pages $166-75$

14 stingon, op. c1t.. p. 275

15. Tupper and MeRejnolds, op. att.. p. 340 
post for their impending notion.

In the meantime Chine had made second appeal to the League of Nations at the outset of the hostilities in Shangha1, th1s t1mo under Art1010 XV of the League Covenant. As previously montioned, conference had boen set up to conduct an Investigation and seok solution. On February 2. durlng the early truce, th18 group had declared thet the inoldent was dofinite tate of war in evergthing excopt offic181 name. Beyond this declaration, however, the conference showed 11ttlo sign of bringing about a solution after houtilit10 had been reatued. The Japanese attaoks were increasing In magnitude exch day, and, becoming desperate, the Chinese decided to invoke the provicion of Article XV whioh permits the Counc12 to refer diepute to the Ioague Assembly. This declsion wes predieated upon the beliof that the maller powers of the world, whioh hed coneiderably nore influence in the Assembly then in the Coune1 1, would be moro symathetio to the cause of a victim of aggraselon than would the great porrers. After vigorous debate, the counoll acceded to China's roqueat, and the issue wa referred to the Assembly on Fobruary 18.

Moanin 110, it was obrious that Japan hed underest1mated tho Ch1nese in Shanghe1. For almost a month thej continued to attack the Chinese positions frontally with only moderate sucoess. It was not unt1l the last days of Fobruary that the Japmese gare up the frontal attacks and rlanike the Chinese positions by morement up the whangpu River. 
(84)

Th1s move gave the Japanese the upper hand, and on February 26 ther doolded to seok an ond to the flghting. The herole resistance of the Chinese and the adverse offect the operst1 on had had upon world public opinion left the Japanese in a diffleult position. Now that their forces had galned the adrantage, they wore anxious to get out of an ombarrasaling al tuation as quickiy as possible. 16

On Pebruary 29 the Counc1l of the League of Nations, acting upon Japan's request, proposed cesseti on of the Shanghal fighting. The powore represented in Shanghal wore in trueted to sit dom at another round table conference with China and Japan to conolude arrangemonts to make the cessation of hostilities dofinite and the withdratel of the Japanese troope complete.17 The United States was Invited to joln this conforence also, but once again stims on refused. He Imodi ately sent word to the Consul Genoral in Shanghal instrueting hil dofinitely not to partielpato. ${ }^{18}$ The United States was till emarting from the Japenese rejection of hor good orflces, and, as has al ready been stated, secretary stimson bed complotely lost falth in the intentions of the Japmese to seok perceful and just solution. This foeling was helghtened by the fact that al though Japan had requested

16 Takeueh1, op. e1t., pp. 376-78

17 The Report of the Eoague Assembly, ope elt., p. 44

18 The Secretary of state to the Consul General in Shangha1, March 3,1932 - The Porelen Reletion of the United Statee, Japan, 1931-1941, I, 208 
(85)

the February 29 proposal for cessation of bostilities, she launched the heaviest attacks of the campaign on Meroh 2 and March 3. This more was designed to leave the Japanose in a position of milltary edvantage and convinced stimson that the United states hould have no part in the conference. 19

The armistice, lgned on Marah 5, provided for an ond to the fighting, return of 211 troops to the positions occupled before January 28 , and the aupervision of this withdrevel by the nations represented at the conference. 20 Thus, the conflict at shanghal camo to an ond rith fow signiflcant results. Losses in the fighting had boen extromoly heavy. The casulties aumbred 5,000 Chinese and 1,500 Japanese wi11tary personnel a well as 8,000 efvilian. Also, constaerablo damage hed been inflieted upon the elty, particularly in the distriet of Chape1. Japen's only gein was that the Chinese did lessen the boyoott followlng the armitice. Unlike Manchuria, the Japanese had voluntarily given up their military gafns because they did not have the publle support at home In this incldent ae they had had in tho Manchurlan question. Chine, on tho other hand, bad gat nod moh in a robirth of national pride in ber horolo rostetance. In The Far Eastern

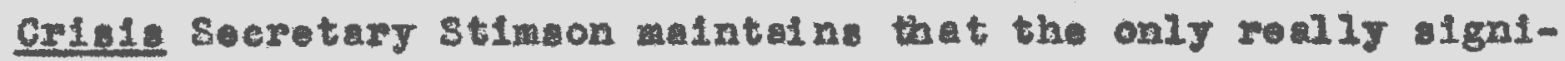
flcant realt of the conflict was that it made plain, ovon

19 Momorandum of the secretary of state, Mareh 3. 1932 - Ib1d.. pp. 205-207

20 Agreement - Conceming the Definitive Cessation of Host111t1 es at shengha1, $\operatorname{arch} 5,1932$ - Ib1d., pp. 217-18 
more than had Monchum a, the true oxtent and character of Japan's polie1es.21

Wile the Shenghal incident wes belng brought to a conclusion, the Japanese were busily solidifying their position in Manchuria. On March 1 the tate of Menchukuo was offlelally formed. The following day the state Department recefved a commulcation from Mr. Haleh-Chieh-shih, the Forelgn Minister of the new atate, explaining the reasons for the creation of this oo-called repub1ic. The unister stated that this Indepondent action of the Manchurlan people was caused by the fact that Chang Hsueh-11ang's military dictatorehip had looked out for 1tsolf and not the welfare of the pople. The people, the Hinlater contimud, hed suffered extremely under the cormupt discipline in offlcial elreles. Further, under the old regime factional strife had precluded any uniflod or stablo goverwent in Manchuria, and anti-forelga policles had groatiy disrapted diplometio relations. 22

On Mareh 4 the pro-Japenese Henry Pu-g1 was Inaugurated president of Manchukuo. The Japanese had token great pains to mike tho ontire affair look like an independent movement, but fov in the world were fooled by it and were uneware that this new republic would be anything but puppot state of Japan. 23

21

Stimson, op. oft., p. 183

22 ur. Hileh Chieh-shih to the Secretary of state, Harch 2, 1932 - The Forelan Relatione of the United Statese The Far East, 1932, III, 597

23 Takeuchl, op. oft.. p. 385 
In $11 \mathrm{ght}$ of these erents, and encouraged by the pos1tion of the Unfted States in the letter to Senator Borah, the Losgue of Hations took 1 ts most positive stop in the dispute up to that time. On Mareh 11 the Assembly, by a vote of forty-five to two, peseed the following resolution:24 "The Assombly . - declareg that it is incumbent upon members of the League of Nation not to recognize any gituation, treaty or agreenent which mey be brought about by means contrary to the Cowenent of the League of Natlons or the Pact of Paris.n25 The purpose of th1s resolution, whose two negative votes came from Japan at whon it was disoted and China who considered it too woak, was not to adjudicate the morits of elther sde in the conflict but was to provide a standard Wioh would gulde the members of the Assembly when the result of the Investigation was presented. The resolution further provided that comitte of nineteen nations would gtudy the rosults of the Lytton Report when it was reoelved and submit 1ts recomendations to the Assombly. 26

The March 11 Resolution was idely denouneed in Japan. The Japanece ergued that Manchurl wes of apcetal cherpeter, and the provistons of the League Covenant wer not applioable to 1t. They contended that the re wae no juotiflea-

24 The Consul General in Geneva to the secretary of State, Narch 11, 1932 - Tme Forelgn Relatione of the United States. The Far Eart, 1932, III, 573

25 The Report of the Ieegue Assemb1y, op. att.. P. 24 26 stimson, op. o1t., p. 187 
(88)

tion for the creation of a comittee to atudy the case. 27

Thus, It was obvious that any recommendation the comittee of Mineteen wight make, based upen the forthouling Ljtton Report, would meot w th conslderable opposition from the Japanese. Although the League did not use the Nine Power Ireaty as the basis for 1 to pronouncement, a did Secrotary Stimson 1n the letter to Senutor Borah, Its polley and that of the Onited statos were almost 1dentical. Jeither had openly placed any blame upon Jepan, but the morel proseure reanting from wach implieation was present in both oqaes, netorthe10s8. Furthor, there now was commen agreonent not to rooogn1ze ong Japanese galns, woh the now otate of Manchukuo, If the evidence proved that those gain were attained through eggreation and a velation of existing intornati onel treaties. The United states was particularly pleased of th the League's action and Indicatod this pleature by the following etatement vent by the Undtod stutes Minister at Bern to the Secretary General on March 12 :

I an instructed by goverment to express to Jou 1ts gretifleation at the action taken by the Ascembly of the League of Hations. My gevernmont is espeoilally gratified that the nations of the world aro united on polley not to recognize the rellalty of results attained in violation of the treatio in question. Th1: is distinet contribution to International Iaw and offers constructive bests for peace.28

It now remined for the rindings of the iytton Comml sion to be presented to the League, and a finel fudgnent

Takouchl, op. elt., p. 379

28

The Report of the League Assembly, op. A1t., p. 49 
(89)

passed. The agreement of the Loague and the United States upon a cormon poliey represented a igniflcant stop in internatfonel cooperation. The fact remalns, however, it had taken seven months to achieve thi comon ground. In the meant1m Japen hed not been get back and had grown inereasIngly hostile and Independent. It was obvious now that whe wes ready to oppose any course of action that might weaken her position or cause her to 1080 the gains she had already made. 


\section{CHAPIER VI}

\section{TAE FINAT JUDENENT}

The day followiag the adoption by the League of the resolution of varoh 11, orfle1al of the nev atate of Manchuruo demanded recognition from the outelde world. Ihis was thet puppet government's way of denouncing the resolut1on. and 1 met with no favorable roction except in Japan. On Maroh 18 the Japanese government expresed etiafect1 on at the formation of the ner state and deolared that recognition bJ Japan would be fortheoming a soon the now regine was - tablibhod upon a flrm foundation. 1

Surprialngly. the Japanose public was extromely a1sappointed at this polioy of the cabinet. The average oitizen farored immediate roognition, but the govemant foared tho Alplonatie consequenoes of such a more at that time. Den though the Seijake1 gorermment was much more symathetio to the militery' point of view then 1 ts procoderaor has been, Japenese natlonallsm bed becom rexy extrome, end the people had begun to 20 e fal th in the ent1re parliamontary ayatom. This type of government was belng blamed for the country's conomle distres and the reel hendling of the lenchurian and Shangha1 quostions. Also, 1t wa nccused of commption and

1 Takeuchl, op. att., p. 386 
(91)

associetion with big business. Fanatiolom was funning rappent in Japen in 1932, and many outstending 11borals relt the - lash of the assasin's blade. The most significant instance occurred on May 15 when band of wen dreased in willtary untform attaked and killed Primo Minlater Inukel in his home.

Even bofore Inuke1' death, nationalitic foeling had rouched the point wore It was orldent that the Japanese sovernment must defy the League and the Inited states in even atronger terms than 1 had alroady dono. Consequently, on Apr11 4 the Japanoso Ambasador warned tho Un1ted States and the League that if the lattor body passed unfarorable judgwent upon Japen there vould be no alternative but to w1 thdrew that nation's delegates from the Assembly. 3 Four days later, In that was apperently another ect of defience, an my was created in Hanchukuo with Jepanese orficers engaged as advi$\operatorname{sor} .4$

In June the Japanese Diet pased a rosolution unenImousif calling for the goternapht to recognige Manchukuo. The resolution contended thet wach move would be the only moane of atabilizing the stuation in Menchuri and restoring tranquility to the Far East.5 Fanatiolsm was so atrong at

2

Ib1d., pp. 380-82

3 Momorandum of the Secrotary of state, Apr11 4, 2932 Phe Fore Ign Reletions of the United States. Japan, 1931-1942. I. 87-89

4 The Report of the League Ascombly, op. Alt., p. 51

5 Takeuch1, op. c1t.. p. 388 
(92)

this point that the government had no cholce but to secede. On september 15, eloven days after the iftion Report had been comploted and sent to Geneva, the Japanese government of 1 c1al1y reoognized Manchukuo. The United State: was notlfied of this action on that sane dey. A tatemont 1 gmod by both the Prime Minister of Manchukuo, Chingho1ao-kB11, and the Japanea Ambessedor to that government, Nobujosh1 Muto, sald: "Japen has recognized the fact that Manchukuo, in accordane with the Iree w11 of 1ts inhabitants, has organised and established 1tself into an independent territory." 6

Japen's recognition of Manchukuo at this th meared tremendous concern among the members of the League and the Unfted States. Loague Counc11 President Eamon De Valera of Ireland we doeply disturbed that such move had como while the matter was at1ll under League discusalon. De Valera contended that in view of the fact that the League wes about to recelve the report of the Lytton Comlsaton, the Japenese uet was an 1rresponible one and was calculated only to prejudice the settlement of the dispute. 7 Thus, with the obvious knowledge thet Japan would oppose and probably defy any strong actIon agalnst her, the League of Vat1one prepared to v1ew the Lytton Report and pass judgment upon the d1sputents.

\section{6 \\ Text of Protocal, September 25, 1932 - The Forelen} Relations of the United States. The Far East, 1932. IV Thahlngton: The United State Government Printing office, $1948), 253$

7 The Consul at Geneva to the secretary of Stato, september 24. 1932 - Io1d.. pp. 275-76 
The report of the Coxalsision of Enquiry, commonly known as the lytton Report, was public on 0etober 2, 1932. Due to ceveral delays in getting the commisal on organized and into Manchurie, the Investigation had not begun unt1l six months after the yukden ineldent had taken plaee. Orer year had passed al noe the begluning of the oride before the report was publiahod. Certalniy this letracts from the accuracy of the zeport. Furthermore, it deals only briefly with the Shanghal question which, deapite the Japanese conteation, wes vital and integral part of the dispute. In fact, the report cane after whet it was intended to provent became falt lecomp11. Nevertheless, it ropresented the most comple te onelyais of the situati on arallablo at thet time. On sunday, Detober 2, it 7:00 A.M., date and timo spect fled by the League, Dr. 8. K. Hormbeck, the head of the State Department' Far Eastern Divialon, opened the packet contelning a copy of the Lytton Report. 8 mo report is extromely lengthy, and for the purposo of sumary in this study it may be divided into four seotions. These divisions include the elatms of Japen that wore dieregarded, the ultimate findIngs, come suggestions, and proposed bats for a satiofactory colution.

The flret olelm of Japan rejected by the Commision was thet Chine we an unorgenlged state. It was admitted that there were evila resulting from china's political and soc1al unrest, but that country was in the boat shape it had 
(94)

been since 1922, and it voula be completely unjustiflablo to disqualify her as a Lergue member a Japan suggested,9

The second disregarded clatw was that China had no soverelgnty over Manchuria. The Commission proelained that the great Imigration of farmers from Chine and the colnowledgments of logal treaties made uanchuria cloarly Chinose.10 Third, Japan's argumont that sho was acting in selfdefonse was repudiated. The combission, howevor, did not exclude the possibility that the officers in charge may have felt they wore acting in that capacity. 12

Finaliy, the alleged Independent and atonomous stetus of Manchukuo was not cocepted. The combisal on contended thet the presence of Japanese troops and the activities of o1vil and milltary offlolal. were responsible for the fornation of the new state, and It could in no way be termed genuinely spontaneous, Independent morement. 12

Thus repudiating Japan's position on Menchuria, the Comission prosented its ultimete Ilndings. It placed full responsibility upon Japan and stated:

Without declaration of war, a largo area of what is indisputablJ Chinose territory has boen forelbiy selzod and occupied by the amed forees of Japen and has, in consequenee of this operation, been separatgd from and declared Independent of the rest of Chinm. 13

9 Report of the Comalselon of Enquiry appointed by the League of Hations, Menchurte (Taghington: The Untted states eoremnent Printing orrice, 1932) p. 17

10 Ibid.. p. 27
11 In1d.. p. 71
12 In1d.. p. 97
13 In1d.. p. 127 
(95)

The report offered two basio suggestions. The firat was that restoration of the status quo would be no solution. The second was that continuation of the present Japanese control in Manehurf would bo equilig unsatiofaotory. It was asserted that the latter conditi on violated all existing international obligations, was opposed to the interests of Chine, and it was doubtful that in the long run it would werre the intereats of Japan. 14

The report conoluded by liating sereral prineiples upon inleh alution ought to be basod. These principles included recogat th on of China's soverelgnty and Japen's speelal Intorest in Manduria, conformlty with all oxisting mult1lateral peace treaties, maintenmec of general order and security against further aggrosion, providons for the settloment of future disputes, ond oconomie rapprochement instend of econconto warfare. 15

The Lytton Roport we unanimous and ineluded no minority opinions or recommendations. Its content was extromoly ploasing to soerotary stimson. In The For Eagtern Crisis he pralses the comisulon for not flinching from draving conclusions on ultimate facts and for learing it to the Loague to judge ingt the facts mont. The secretary also complimented

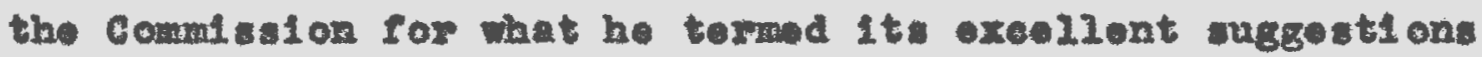
for a olut1on. 16

$$
\begin{aligned}
& 14 \text { Ib1d.. Pp. 127-28 } \\
& 15 \text { Ibld.. pp. } 130-31 \\
& 26 \text { stimon, ope e1t.. p. } 206
\end{aligned}
$$


(96)

The Japanese reaction to the report, howorer, wes a great doal different from that of $s+1 m$ on. The Japanese press was unanimous in conderaning it. The soctione that met partieular oritioiam wore the denial of Japan's olain of selfdefonse, the 1mputation that Manohuluo was "Made in Japan". and the rerusel to pass any judgment on the question of the Chinese boycott constituting violetion of international 1aw. 17 on this lat point, however, it should be noted that the Commission ald recommend the cessution of economit warfare, even though it did not mention the legality of the boycott.

The puppet goremment of Manchukuo also denounced the report vigorously and sald in atatoment lasued to tho American Consul General at Mukden: Manohulue offialal are very incensed and excited. Wo are elmply ignoring the report, Manchukuo has nothing to do with it or the League. The report has agerarated the world ol tuat1on."18 Meninile, the Japenese goverment was determined to carry out its policy, and Its delogate to the League, Youke Matmoke, in a statement made to that body on Forember 19, warned that eny atterpt to do anthing derogatory to the dignity of Japan would leave hor no recourse but to witharas from the loague. 19

17 Takouchi, op. e1t.. p. 399

18 The Consul General at Murden to the Minister in China, October 6, 1932 - The Forel mo Relations of the United states. The Far Bet, 2932, IV, 290-91

19 The Minister in switzerland to the secretary of State, Jorember 19, 1932 - Tb1d.. P. 349 
(97)

The handwriting was on the well wen the League counc11 opened 1 tg debate on the contents of the Lytton Report on Norember 21. A woek later the Councll roted to put the issue before the Assembly. Following the prorilans of the Mereh 11 Resolution, the casembly referred the question to the combltte of nineteen nations on December 9.20 The Committee of Hineteen first attompted to porform 1t's duty by seeking conelliation. Both the United States and Russia were Invited to participate In this effort. Secretery Stinson was reluetant to cooperate In this venture ince he foared a delay to attempt conelliation might weaken the flnal League action. Norertheless, he agreed to go long with it in order not to hinder the comittee's work. Stimgon's approhensions proped unnocessary as Japan rejected both the United statea and Rusula a partios to conelliation and doclared it would aceopt no solution which dented the existence of Manchulruo, 21

In complete defience of the Committo of Iinotoen's offort at conel11ation, Japan then renowed hor miltary operations. On January 1, 1933 Japanese troops attacked the elty of shanhalkwan, located just south of the Great WaIl at its eatern extremity. Shanhaikwan was of extrome Importance because 1 was the gaterry to the Chine se provinoe of Johol wh1 he the Japenese considered to be rightfully part of Manchukuo. The operation proved to be ahort one, and Shanhalkwan foll in two days. Thore seomed to be 11 ttlo doubt

\footnotetext{
20 Takouch 1, op. o1t., p. 402

21 stimson, ㅇ․ alt.. p. 225
} 
now that en invasion of Jehol was imminent. 22

As soon as the news of the ocoupation of shanhaikwan had been rocelved, Secretery Stimson held another conference w th the Japanese Amberador. Tho lotter's explanation of the affair was not unexpectod. He otated thet the Chinese hed fired the rirst whot, and Japan was acting in self-defonge. Again the aseortion was mede that Japon hold no torritorill abitions, stimson, obvlousiy annoyed at this tine-worn explanation, repllod that Japen had old the 8 our thing bout Mancharia and was now adding the provinee of Jehol to her dowain under the same pretense. The Ambasador's answer indloated juat how far Japan's hostility hod dereloped. He declared that no Japanea cabinet thet compromised on the Manchurtan situetion could survive, and the incident must be considered elosed. 23

As expected, the capture of Shanhalkwan paved the way for the Invasion of Jehol. Thls now military opertion, coupled w th Jepan's unglelding att tade, convineed the comnttee of Hineteen that conolilation was impossible. The committe then proceoded to draft its report inlch was prosented to the Assembly on Fobruary 21, 1933. The Cormitteo of Nineteen aceepted completely the findings of the Lytton Commast on. It recognized that both Japan and China had legitimate grieraneos bofore September 18, 1931 but declared that no responsiblitty oculd be placed upon China for the event which ocourred after that date. The report further denled Japen's argment of eelf-defense,

22 The Report of the Leegre Assembly, op. alt., p. 59

23 Paece and $\operatorname{war}$, op.ett., pp. 5-6 
(99)

recognized China's soverelgnty over Manchur1a, denled the oxistonce of Manchukuo as angthing but puppet state of Japan, and urged that no nation recognize it as on independent state. The report than concluded by recommending that nogotilition: be opened betreen Japan and ChIna to seok solution based upon the suggestions and principles presented by the Lytton Combsion, ineluding the recomendation that Chine give up the use of the commorcial boyeott. 24

The report of the Committee of Inoteen placing full blame upon Japan was adopted by the Leagie Asaemig on Februery 24 with onls one negative rote, Japen, and one abstention, S1am. The Japenese delegate, Katauoka, then deelured that Japan and the other membor of the League entertainod aifferent viers on how to achleve peace in the Per East and thet his government had reached tho limit in its endeavor to cooperate with the League on the Sino-Japenese questit on. Jpon 1saring th1s statemont, Hatauoka and his staff walkod out of the Asacab1y. 25

Secretary stimson wa at this point facel with problem due to the fact the Republican admintration had been defeated in Novembor of 1932. Stimson was deterained to bring bout somo conelusion to the affalx but was handloapped in that he had no asurance that the new Domoeratic adninistrati on would not rejeot his polloy. This coneern proved to be

24 stimson, op. e1t.. p. 227

25 The consul at Geneva to the secretary of state, Fobruary 24. 1933 - The Porel gn Releti ons of the United Strtes. The Far Eant 1933, III Tashington: The United states Gor ornment Printing off 100,1949$), 205-208$ 
short lived, howerer. At the suggestion of the newly elected prosident, Frankiln D. Roosevelt, Stimson made $\nabla 18$ it to Hyde Park. At this mooting Rooserelt essured the Secretary that his Far Eastern polley would be rollowed by the new administration. 26 Thus, without any fear that the Democrate might alter his polley, stimson Informed the Lague on Februaxy 25 that the views of the United States completely colnoldod with the Loague' findings. He also promised that the Amerlean goverwment would ondervor to glve rull support to the League, while reserving the right of independent judgmont. 27 The United States had chosen to cast 1ts lot with the Loague in imposing wat now constituted strong moral prosoure upon Japan and in refusing to roeognize Manchukuo, whtoh was now adjudged to have been created in violation of the multi-nation peace treatios. But, despite its implicetion, this policy did not achlove Its intended rosults. On March 25 the state Department rocelved word that Japen rould withdraw from the Legue of Nat1ons. Two days later a statemont to this offeet wes sent to Goneva, and the w1 thdrawal was off101a1. 28

The poliey of the United States and the League had recelved nothing but deflance from Jepan. Moral condemation

26

Stimson, op. c1t., p. 225

27 The report of the League Assembly, op. oft." p. 86

28 Nomorandum of Under Secrotary of State Phill1ps. March 25. 1933 - The Forelgn Rolatione of the United States. The Far Eeat. 1933. III, 253 
(101)

had resulted in that nation's withdrawal from the League, and the policy of non-reoognition of lianchuikuo did not force the Japanose to disalve that sate. Furthermore, in an oct of complete hostility, the Japanese had continued thoir aggression Into Jehol and had successfuliy conquered thet pxovince by uay of 1933.29

In short, oven though be had boen condemned by morld pablic opinion, Japan had galned viotory in 1 ts conflict -1th China. American poliey and that of the Loague had not been effoctive in preventing this vietory. Neither hed this poliey succeeded in grinlng respeot for the international perce treatles nor had it brought any satisfaction to China. Finally, the taste of viotory was pleasent to the Japanese. They would now present to the world their "lworroe Dootrine" for Aola. They would continue to push forward in fanatie drive to dominate the entire Far bast at the riak of foroing the United States into complete and total war. 
CHAPTER VII

COHCLUSIOH

The SIno-Japanese dispute during 1931 and 1932 was the first in the serles of diplowatio erises leading to World War II. Further, it represonted the flrst major defent for the League of Nations. The inability of the League to bring about successful solution to this question not only encouraged Japen to further aggresston but probably enoouraged the totaliterian powers of Europe as well.

Two definite reaults of Anerican polley in this arfalr oun be seen. Flrst, it nelther curbed Japan's ambitions nos provided any satiafretion to China. Second, it contributed to the reakening and collapse of the League. Any polley that doe not sueceed is open to considerablo critieism. It is much more diffieult to make the doclsions that affect history, howerer, then it is to pass judgment on those deciston over twonty-seven jears later. Wevertholese, there were two balc exrors in the American polloy in this conflict that need to be pointed out. The most fundemental mistake was to stay out of the dispute publicly for over two manths in order to gito the cirlilan eloment in the Japanose government every posslblo chance to work out a olution by Itself. Ideallstically, this polloy was good one. It would have been better for 


\section{(103)}

all parties Involved if the Japanese could heve worked out the problem by themselves. Certeinly the record of Baron Shidehare commanded confldence in his good Intentions and w111Ingness to sook a settlement satisfactory to all parties. The diffloulty was that shidehara and the liberal element had very 1ittle chence to overcome militarism in Japan. American polloy was ectually gamble that this group would be able to gain control. It was gamble with little hope of uncoess. The United States atayed out of the alspute inftially in ordor to help Shidohara by not fanning the tlames of nationaliam. As it turnod out, however, this polloy had the reverse offect. Although American opposition inght have oontributed to Japanese natl onalism, it probebly would not have onhenced this foeling noarly as moch of did the milltary auecesses in Manchuria.

Secrotary Stimson took chance which, if it had worked, would have constituted great diplonatie viotory. He did not, howerer, seem to take into consideration the consequences that would result if it ralled. Furthermore, there 1. no evidence to 1ndicate that he orer made an effort to sook the advice of hi envoys elose to the altuation as to the possibility of the liberals regaining the dominant position in Japan from the military.

The milltary's advantage of di rect access to the Emperor, the presence of General Minumi in the cabinot, and the growing foeling omong the Japanese people that Manoburia represented the answer to their economlo problems vere indications that Japan would not return to Shidehara's polley of 
conciliation. Secretary stimson ald not heed thea indicat1ons. Instoad, he followed polley that led to fallure and gevo Japan the opportunity to gain completo domination orer Manehur1a.

The second exror in the Amerlean polley was the fallure to cooperate fully with the League. There can bo no doubt that part of the blane for the inefrectiveness of the League In handing this dispute belongs to the United states.

From Its beginning. the Loague was hampered by the fact thet it did not include the United States anong 1 ts members. The success of collective action depends upon the cooperation of all the great powers. The League never had any asurance that the Unitod States, certainly one of the world's greatert powers, would provide that cooperation. Even though the state Depertment had declared 1ts willingness to apport the League in 1 ts handling of the Manchurian question, the members of that organization st111 remembered the rejection of Foodrow W1180n' drean by the senate and later by the Amertoan eloctorate. With good reason, there was considerable doubt as to the extent to which the league could count on the Un1ted States.

Instead of showing 1 ts willingness to cooperate at orery possible opportuntty, in order to bulld confidence in the Intentions of the United States among the Loague nembers, the state Depertmont adopted hesitent approan. Tho withdrawal of Prontiss Gilbort from the League motings just prior to the pessage of the resolution of Oetober 24,1931 wa: a definite Indication that the United States would back the 


\section{(105)}

League only if it took acti on that $t$ ith complete Americen favor. The several referrals to the right of independent Judgment, and the later aloofness of Charles $A$. Dawes were further ind cations of thls sme view. One reason the League moved cautiousiy wes to arold rejection of its action by the Onited States, and this caution contributed to 1ts fa11ure in the affalr and erentual collapse. It took the League serenteen months to condem Japan. By that tim the Japanese had achleved their objective: also public opinion in their country would not have approved of any attempt to relinquish what had alroady been gained.

The question now arises as to the possibility of a enceeseful settlement of this dispate, desplte the two basie errors of the state Department. This would have required atronger action agatnst Japen in early 1933 than woral prossure and non-recognition of Manohukuo.

One possibillty would have been the use of armed force. The Eorean Inoldent of 1950 to 1953 proved that armed intervention on a Ilmited sealo oan be effoctive in halting eggresal on. The Korean conflict, however, was not the result of the iggression of major power as was the Manchurian inc1dent. The use of armed foroe against Japan would have meant a full scelo war, and that was what ororyono was trying to prevent. Furthorrore, lthough the world is able to eccept the idea of amed intervention in the ninotoen fiftios, it wa not ready for wach course of action in the thirties. Dr. S. X. Hornbeck atates that at no time was there in con- 
nection with thi Ineldent serfous aggestion or consideration of poalble resort... by the United statos to arred foroe." 1

The other alternative, then, would have been oconomic sanetions. Thore 1 no queation that such move would heve had a tromendous of rect upon Jap an. That nats on's shortage of raw material had made forelgn trado v1tal to her welfare. To eut off th1 trede would hare beon an ceononie di:anter and would have necossitated dratic action. If raced Ith econcale anotions Japan would be confronted with two ilternatires, to beek dom or to ficht.

The very noture of the Japanese people, wo w111 go to groat lengths to arold humilation, indieates they would not have backed down. Further eridence of this is found in atter from the nowly appointed Ambasador to Japen, Joseph Grew, to secrotary Stimeon written in August of 1932. The Ambasador stated of the Japanose milltory machine: "It has been built for war, foels prepered for war and would welcone wer. It has never yot boen beaten and powsesses unlimited self confidence." 2

There wes some support for anctions in the Unfted states. The American Bojoott Association was ereated to aupport such o course.3 In general, howerer, the rast najortty

1 stanley X. Hornbook. The United States and the Fer Baft (Boston: The World Perce Foundation, 1942) P. 30

2 Peace and War, op. a.t., p. 6

3 Tupper and McRejnolds, on. elt., p. 336 
of Amorican publ1c opinion, particularly the press, was vehemently opposed to sanctions. 4 Most of the leading congrestonal flgures were also opposed to them. Sonator Borah was quoted just before the pasage of the Longue's Docember 10 resolution saying:

When the United States omploys 1 ts good offleos in every reasonable way to bring about poce, it has done all it can do or hould do. Ho treaty no duty derolving upon peace-1oring ngtions requires or permits the United States to go furthor. 5

Final1y, both President Hoovor and Secretary Stimson left no doubt that they too opposed coonomic saneti on: etrongly. stimeon openiy atated that he rould "do nothing that in anyway would comit the United states to such a course. $n 6$

Thus, the use of economie sanetions would not here been supported by the United States. Anj policy that mot with such trong opposition, both from the leading figures in the administation and the public, would not have been posstble. Further, there is 11ttlo doubt that suoh polloy, if it had been attempted, would have lod the United States into war it dofinitely did not want.

It is the conclusion of thi thesis, therefore, that the mistakes of the state Department, the inftial delay and the fallure to cooperate hily a th the League, were fatal.

4

Iold.. p. 337

5

smith, op. 01t., p. 180

6

stimon, op, oit., p. 99 
The only possible pescerul solution to the problem depended upon Immediate moral proseure, close cooperati on botween the Onited States and the Loague, and a derlnite effort by the nations of the world to as 1 ist Japan to overcome her oconomic probloms. Desplte the obvious guilt of Japan in this dispute, one mast recogalse that her coonomic situation-caused by her orerpopulation, ahortage of rew materials, and unfavorable balenee of trade-was partly reaponglble for hor aggreselve att1tude. Anj peceeful cottlement would have to be sypathetie to thin situati on. The Iytton Report suggested economfo rapprochemont instead of conomic warfare.7 Such more would require more then Iffting of the Chinese boyeott which wes the purpose of the Commission's suggeation. It would roquir. conselentious effort on the part of all nations to establish free trade with Japan ond decrease Imelgration restrietions. It 1. encouraging to noto that as this thosis is being writton, In 1958, the wealthier powers of the world are beginning to recogntze the need to combine oconomic ald if th political agreomonte in solring diplomatio problems. It is unfortunate that thls awarenoss was not os prominent in the ninoteen thirties.

There 18 abolutely no guaranter that th is approaeh to the question would have been suecessrul. It is ontirely possible that econcmic aseistance to Japan would not have ourbed militariem and extromo nationalism in that country. A180, there 1s no assurance that moral pressure agalngt Iapan, 
which fallod in oarly 1933, would have sucesdod in the fall of 1931. Fina11y, there is also no guarantee that the League of Vations would have been wliling to take prompt action even If it were aured of full Americen cooperation. The fallure of the leading nations of Europe to support the Stimson Doetrine in January of 1932 Indiostes that the Loague might have been cautious regardies of the attitude of the Unlted states. The people who claim that war with Japan wes inevitable may be correct.

One can draw conoluaion on the miatakes made in hiatory, but one can only speculate on what might have happened had those mistakes not been made. There is no assuranee that the history of the nineteen thirties and nineteen fortios would have been any ifferent had immodiate moral prossure been Invileted upon Jepan jolntiy bg the United States and the League and had this condemnation been coupled with a incere effort to seok solution to Japan' oconomic alficulties. As a result of the ovidence presented earlier, howerer, It 18 the firm bolief of this writor that such an approach represented the only possiblilty of a peaceful and permanent settlement. 


\section{BIBLICRRAPHI}

\section{Books}

Bemis, Samel F1agg. The United Steteg as a Vorld Pover. Hew Tork: Honry holt and Co., 1950.

B1seon, T. A. Ameriean Poller in the Far Eagt 1931-2942. Now Tork: Internationol secretariat Institute of Paciflo Relations, 1939.

Perre11. Robert H. Americen Diplaneer in the Oreat Depres10n. Hew Heven: Talo University Prets, 1957.

Hornbeok, Stanloy K. The United States and the For Eest. Boston: Forld Peace poundation, 1942.

Stimson, Henry I. The Far Featern Grie1s. How York: Harper and Brothers, 1936.

Smith, Sare R. The Monohurien Crtale. Mow York: Columbie University Press, 1940.

Storry, Richard. The Double Patriets - A Study of Japanese Metional1 em. London: Chatto and Windus, 1957.

Takeuoh1. Tatauj1. Mer and DIplomeer in the Japanese Fipire. INow York: Doubloday, Doren and Co. Inc., 1935.

Tupper, Fleanor and HeRejnolds, Georgo E. Japan in Amertean Pubile OpInion. Fow York: Mackilian co., 1937.

Pub11e Documente

United states Dopartment of State. Forelan Belationg of the United States - Did comatie Papers. The Far East 1932. V01. III. Vashington: Dnited state Government Printing orf1ce, 1946 .

United states Dopartmont of state. Forelgn Belations of the United States - D1plomatic Papers. The For East 1932. Vols. III and IV. Tashingtont United states doversment Printing off10e, 1948. 


\section{(111)}

United states Department of Stato. Forelgn Relations of the United States - Diplomatic Papera. The Far East 1933, Vo1. III. Washington: United States Government Printing off10e, 1949 .

Onitod states Department of state. Forelgn Relations of the United States - Diplomat1c Papers. Jepen 1931-1941. Vo1. I. Washington: United Stater Government Printing orfice. 1943.

UnIted statos Dopartmont of state. Rease and Ner - Initad

States Forelgn Polloy 1931-1941. Wanington: Dopartment of State Publication $1983,1943$.

\section{Reporte}

Lengue of Hatl ons. The Verdict of the Lesue - Chine and Japen In Manchuris. Report of the Assembly. Boston: World Perce Foundation, 1933.

Lengue of MatLoas. Manchuris. Report of the Coimlesion of Enquiry. Washington: The United States Government Printing orr1 oe, 1932. 